Deniz, H. \& Demir, S. (2019). Teacher Opinions on the Applicability of Process Based Writing Approach. Bartın University Journal of Faculty of Education, 8(2), 437-456.

Bartın University Journal of Faculty of Education, 8(2), 457-486

Bartın Üniversitesi Eğitim Fakültesi Dergisi, 8(2), 457-486

buefad.bartin.edu.tr

\title{
Teacher Opinions on the Applicability of Process Based Writing Approach*
}

\author{
Hacer Deniz ${ }^{a}$, Sezgin Demir*b
}

\begin{tabular}{l} 
Article Info \\
\hline DOI: $10.14686 /$ buefad.426785 \\
\hline Article History: \\
Received 24.05.2018 \\
Accepted $\quad 04.02 .2019$ \\
Published $\quad 30.06 .2019$ \\
\hline Keywords: \\
First language education, \\
A process based writing \\
approach, \\
Writing ability, \\
Writing education. \\
\hline Article Type: Research Article
\end{tabular}

\begin{abstract}
Process based writing approach that aims to grade it in order to facilitate the writing process is an approach based on the structuring and digestion of knowledge on the mind. İt aims to teach students how to use and improve writing skills. The purpose of this research is determining the opinions of the Turkish teachers about the applicability of the process based writing approach. The research was carried out in phenomenological form from qualitative patterns and analyzed data by content analysis method. The study group was determined on the basis of volunteerism through the gradual sampling method consists of 14 Turkish teachers working in Elazığ province. Face-to-face interviews were conducted with the semi-structured interview form developed by the researchers and the findings were tabulated by determining frequency distributions. As a result of evaluating the opinions of the Turkish teachers, it was found that there are serious difficulties and deficiencies about the applicability of the process based writing approach. These difficulties stem from problems such as excessive time in practice, lack of information on the subject during the preparatory phase, and the inability to learn artificial language skills.
\end{abstract}

\section{Süreç Temelli Yazma Yaklaşımının Uygulanabilirliğine İlişkin Öğretmen Görüșleri}

\begin{tabular}{|c|c|}
\hline \multicolumn{2}{|c|}{ Makale Bilgisi } \\
\hline \multicolumn{2}{|c|}{ DOI: 10.14686/buefad.426785 } \\
\hline $\begin{array}{l}\text { Makale } \\
\text { Geliş } \\
\text { Kabul } \\
\text { Yayın }\end{array}$ & $\begin{array}{l}\text { mişi: } \\
24.05 .2018 \\
04.02 .2019 \\
30.06 .2019\end{array}$ \\
\hline \multicolumn{2}{|c|}{$\begin{array}{l}\text { Anahtar Kelimeler: } \\
\text { Ana dili eğitimi, } \\
\text { Süreç temelli yazma } \\
\text { yaklaşımı, } \\
\text { Yazma becerisi, } \\
\text { Yazma eğitimi. }\end{array}$} \\
\hline $\begin{array}{l}\text { Makale } \\
\text { Makale }\end{array}$ & $\ddot{u}:$ Araştırma \\
\hline
\end{tabular}

\begin{abstract}
$\ddot{O} z$
Süreç temelli yazma yaklaşımı; yazma sürecini aşamalandırarak yazma işlemini kolaylaştırmayı, ögrencilerin yazma becerilerini nasıl kullanacaklarını öğretmeyi ve bu becerilerini geliştirmeyi amaçlayan, bilginin zihinde yapılanmasını ve özümsenmesini temel alan bir öğretim yoludur. $\mathrm{Bu}$ araştırmada Türkçe öğretmenlerinin süreç temelli yazma yaklaşımının uygulanabilirliğine yönelik görüşlerinin tespit edilmesi amaçlanmıştır. Araştırma, nitel desenlerden fenomenolojik türde gerçekleştirilmiş ve veriler içerik analizi yöntemiyle analiz edilmiștir. Așamalı örnekleme yöntemiyle gönüllülük esası temel alınarak belirlenen çalışma grubu, Elazı̆̆ il merkezinde görev yapan 14 Türkçe öğretmeninden oluşmaktadır. Türkçe öğretmenlerinin görüşlerinin değerlendirilmesi sonucunda süreç temelli yazma yaklaşımının uygulanabilirliği konusunda ciddi zorluklar ve eksiklikler yaşandığına dair görüşler tespit edilmiştir. Katılımcılar tarafından bu zorlukların, yaklaşımın uygulamada fazla zaman alması, öğrencilerin hazırlık aşamasında konu hakkında yeterli bilgi edinememesi ve yapay dil becerilerini ögrenememiş olmaları gibi sorunlardan kaynaklandığı belirtilmiştir.
\end{abstract}

\footnotetext{
* This study was formed with reference to the master degree seminar named "Teacher Opinions on the Applicability of the Process Based Writing Approach". In addition this research was presented as verbal announcement in Vth EJER Congress, which was performed in Antalya, on 2-5 May 2018.

*Corresponding Author: sezgin.demir44@gmail.com

${ }^{a} \mathrm{PhD}$ Student, Firat University, Faculty of Education, Elazig, http: //orcid.org/0000-0002-2604-1893

bAssist Prof. Dr., Firat University, Faculty of Education, Elazig, Turkey, http: //orcid.org/0000-0003-1810-3481
} 


\section{Introduction}

Writing, which is a communication tool peculiar to humans, is a tough language skill, which requires more mental and physical activity compared to basic language skills in terms of the processes it includes. Writing, which requires more different transactions compared to speaking, is not a difficult to acquire even though it looks harder than speaking. (Şahin, 2007). Writing is acquired and it completes its development at the final stage of language skills therefore it is considered as a difficult skill. In addition because of the active use of other language skills it requires accumulations like thought, imagination, vocabulary development and a series of preparation (subject, genre, purpose, etc. determination) (S. Maden, Dincel \& A. Maden, 2015). During the writing, the challenging process that continues until the step, which is a concreting tool, as the ideas forming in mind, supports this situation.

The writing skill supports the individual's development in terms of mental, emotional/affective and kinetic aspects. Writing learning area is performed in two stages; one of them is learning fundamental information and obtaining the skills at a level in which they can be used and the other one is learning how to use these factors acquired during written expression (Gömleksiz, Sinan \& Demir, 2010). The mental transactions such as analyse, review, questioning, association and control arrange the structure of the mind and develop several mental skills (Güneş, 2007). Whereas the product based writing approach, which was developed by behavioural approach is composed of transferring ideas onto the paper according to certain rules (Sezgin, 2016). With some rules this method affects the students in a negative way in terms of their writing attitudes and constrains them producing original and creative texts. Since product based writing approach was not considered successful it was abandoned with the beginning of constructivism.

In contrast to behaviourism constructivist approach; activates the student; and adopting an understanding based on the process not on the result, aims to make the students acquire skills like critical thinking, questioning, comparing etc. (Gömleksiz, Sinan \& Demir, 2011). With the start of adopting constructivist approach in education, process based writing approach (PBWA) was started to be used in writing education as well. Together with using the plans commonly and constantly, this approach is being used in order to get information, structure, develop, correcting and improving behaviours and it foresees the students possessing cognitive awareness in every stage arranging the process while the students are transferring the information (Karatay, 2011). PBWA gives the teachers the opportunity to give positive instructions to their students providing them to write feedback and make evaluations for what the students write. In addition it enables the students to evaluate themselves and correcting their own mistakes developing the writing process step by step. Also it affects the text quality of the students in a positive way developing their ideas and self-confidence for writing.

PBWA considers writing as a series of stages that start from a certain point and it considers teacher as a guide who provides the development of information and skills (Badger \& White, 2000). This approach focuses on the development of the text revising it constantly accordingly feedback is always taken from the teachers and the peers (Nordin, 2017). The feedback includes all aspects of the text such as content, style, spelling and punctuation. Form this aspect it notices the language rules that the traditional writing approach aims however it is not a basic purpose but it is considered as a tool to develop writing skill. When the students have the problem of lack of information they benefit from three resources; teacher, other students and sample texts (Badger \& White, 2000). An environment, in which the teacher and the students are always interacting, provides the information and skills to become more active and absorbed better. In addition benefiting from sample texts is important for the children's language development, vocabulary and writing skills. The sample texts presented are not for the students to imitate as in the traditional approach but for increasing their prior knowledge.

PBWA is a teaching method, which aims to teach the students how to use and develop their writing skills; rather than teaching only information, it focuses on the use of the information and bases on the information being organised and absorbed in mind. Karatay (2014), who emphasises that the students must have cognitive awareness in every stage focusing on thinking process, argues that by this way skills such as deciding, thinking independently, analyze, synthesis, problem solving and learning to learn are developed. Not only does it provide the students act freely in their imaginary world and in terms of expressing their ideas, it also contribute their language, aesthetic and art developments enabling them to produce original texts. The most important components of the PBWA, which considers the writer as the creator of the text, are creating and producing processes (Silva, 1990). Considering all these benefits it can be said that it must applied in terms of the development of writing skills. 
When the researches carried out within the literature are examined, it is seen that the theses performed within the experimental model are more (Reimer, 2001; Sezgin, 2016; Ülper, 2009; Erdoğan, 2014; Selanikli, 2015; Aksu, 2015). In accordance with the studies in which the effect of the PBWA on students' writing skills; the effect on 5 grade students' development in essay writing skills (Güvercin, 2012), the effect on 8 grade students' development in informative text writing skills (Şentürk, 2009), the effect on 5 grade students' development in written expression and creative writing skills (Sever, 2013) were searched and as a result of all these it was determined that PBWA contributes to the writing skills of the students. It is seen that the articles on this issue are generally carried out with quantitative method and the effect of the approach on writing skills is focused on (Bayat, 2014; Graham \& Sandmel, 2011; Kallestinova, 2017; Johari, 2018; Y1lmaz, 2012). However it was not clarified how the teachers, who are the applicators of this approach, adopted and apply this model. This research was carried out considering the fact that the determination of the views of the teachers', as the applicators of the PWBA and direct the process as a guide, about the issue will bring a different point of views to the situation.

\section{The Purpose of the Research}

The purpose of the research is the determination of the Turkish language teachers regarding the applicability of the PWBA. For this general purpose it was aimed to determine the contribution of PWBA to the writing skills of the students, in the preparation stage determining the subject and the basic concepts, in the planning stage determining the writing plan and parts, forming the idea plan and the applications during the correcting stage, the reactions and attitudes of the students during the publication stage, the problems encountered while the PWBA is carried out during the class, the assessment and evaluation methods used with reference to PWBA, and the determination of the participants' views regarding how PWBA affect the students' attitudes towards writing, their will to be a writer and their interest for literature.

\section{Method}

In this research, which was carried out in phenomenological type as one of the qualitative research patterns, one on one interview method was used, and for the analysis of the data content analysis was preferred. The studies in which interview method was used; are the philosophy and psychology based researches, in which the individuals describe the common meaning of their experiences about a phenomenon with the help of trust and empathy based interviews (Creswell, 2016b; Creswell, 2016a; Büyüköztürk, Kılıç Çakmak, Akgün, Karadeniz, \& Demirel, 2017). In qualitative researches, that have three different methods like open ended interviews, direct observation and written document analysis it is aimed to determine the experiences and perceptions of humans with content analysis (Patton, 2014).

\section{The Study Group}

The study group of the research was determined with progressive sampling method, since it was not possible to reach every Turkish language teachers in Turkey as the target population, in order to provide accessibility the Turkish language teachers, who works in public schools in Elazığg, were determined as sub-population. On voluntary basis new interviews were performed by the researchers until they were convinced to have enough data and when they started to think that new views were not coming from the participants the study group was completed in the interview performed with the 14th participant. In the researches, in which interview technique was used instead of the quantity of the sample number, whether the sample meet the information needed is checked (Türnüklü, 2000). Information on the participants of the interviews:

\begin{tabular}{llcc}
\multicolumn{1}{l}{ Table 1. Participants' } & information & n & \% \\
\hline Gender & Female & 9 & 64.29 \\
& Male & 5 & 35.71 \\
Education status & Bachelor & 13 & 7.14 \\
\multirow{2}{*}{ Title } & Master's degree & 1 & 92.86 \\
& Teacher & 13 & 7.14 \\
Service period & Expert teacher & 1 & 92.86 \\
& 1-5 years & 8 & 57.14 \\
\hline
\end{tabular}

The study was carried out with 9 female and 5 male totally 14 Turkish language teachers, who work actively in public schools in 2017. Only one of these teachers is an expert teacher, 1 is a master's degree and 6 teachers have 6 years and more experience. 


\section{Data Gathering Tools}

An interview form, which was developed by the researchers and consists of 10 open ended semi structured questions, was used as data gathering tool. With reference to literature the draft form prepared was presented to the views and evaluations of the 5 Turkish language teachers who work actively. Afterwards for content validity the views of the academic members, who work in Fırat and Nevşehir Hacı Bektaşi Veli universities in Turkish education departments, were taken and in this direction after making necessary corrections the interview form was put into final form. In order to learn the idea, attitude and behaviours of the participants and the reasons of all these (Karasar, 2009), as a result of the one on one interviews performed the data gathered was recorded. With the purpose of providing independent thinking open ended questions were utilized, and in case of need the semi structured interviews were carried out asking follow-up questions.

\section{Gathering and the Analysis of the Data}

After putting the data into writing on computer and making it checked by the participants the "credibility" of the research and giving the participants information about the process of the study the "accessibility" of the research was attempted to be provided. The interview data obtained was analysed using content analysis method. The data analysis; contains coding the data, assigning labels for every unit, and grouping the codes chosen from the expressions of the researchers and participants or the concepts used in social or human sciences under themes (Creswell \& Plano Clark, 2015). The categories formed according to the views of the participants were constituted basing on the participants views with reference to literature and it was attempted to provide "category accuracy". Within the study bringing similar answers together the frequency of the answers in all answers were tabulated and the frequencies were commented under the tables. In qualitative researches coder reliability is different coders' coding the same text in the same way or the same coder's coding the text in different times on the other hand category reliability is the categories' being accurate and clear (Bilgin, 2014; Sönmez and Alacapınar, 2016). Within this research the data was analysed twice in different times by the same coder, at first step the concord was aimed to be above $70 \%$. By this means it was aimed to provide "coder reliability" (Miles \& Huberman, 2016). In order to provide coder reliability Miles and Huberman's (2016) "Reliability=Consensus Number/Total Consensus + Dissensus Number" formula was utilised. Considering the fact that the concordance percent was $73 \%$ the study was found adequate in terms of coder reliability.

\section{Findings}

The findings obtained from the interviews were commented with reference to the literature according to the questions and forming the sub- purposes of the research asked in the research.

Table 2. The views of the participants about "the contribution of PBWA to the writing skills"

\begin{tabular}{lccc}
\hline The contribution of PBWA to the writing skills & Positive & $\begin{array}{c}\boldsymbol{f} \\
\text { Negative }\end{array}$ & Total \\
\hline Transferring the ideas & 7 & 3 & 10 \\
The attitude towards writing & 6 & 4 & 10 \\
Multi assessment and evaluation & 9 & - & 9 \\
Cognitive skills & 7 & - & 7 \\
Planning & 6 & 1 & 7 \\
Personal development & 6 & - & 6 \\
The use of standard language & 4 & 2 & 6 \\
Constructivist approach & 6 & - & 6 \\
Preparation & 5 & - & 5 \\
Progressive writing & 4 & - & 4 \\
Time & 2 & 2 & 4 \\
Applicability & - & 2 & 2 \\
Fundamental language skills & 2 & - & 2 \\
\hline
\end{tabular}

The views regarding the contribution of PBWA on students' writing skills mostly focus on the issues such as transferring the ideas and the attitude towards writing. The experiences and the observations of the participants indicate that PBWA develop the skills o the students for transferring the ideas on paper in a more effective and regular way. However, since writing, which is an artificial language skill, requires obeying certain rules, it is stated 
that the students have difficulty in transferring their ideas on paper and they come through data loss. It can be said that reasons like students' prejudice for writing, avoid writing, the writing process taking a long time and it requires patience affect the attitude towards writing in a negative way. Using multi assessment and evaluation; the students seeing their mistakes, take lessons from their friends' mistakes, can support their writing skills development providing them evaluate themselves in accordance with the feedback they take and enable them correct their mistakes. It can be said that PBWA develop writing skills through supporting the effective use of cognitive skills, development of planning skills, personal development, the use of standard language and constructivist approach. Nevertheless, there were some views stating that students' tendency for writing in a short time without planning and the use of the standard language's requiring certain rules affect their writing skills development in a negative way. While the application of preparation stage and progressive writing contribute to the writing development directing students to reading and socializing in the process may support the fundamental language skills as a whole. It can be said that while extending the writing process over a period of time give the opportunity to think longer and use imagination more; inadequate lesson time and the development emerge after a long period of time affect writing skill in a negative way. It was stated that this situation.

P-6. It teaches our students a three stage writing model; before writing, during writing and after writing. It enables them to be more conscious and prepared for the writing process. Actually process based writing approach teaches the students that they should not write randomly while they produce a text but to follow certain processes. In addition it emphasizes to be careful about the spelling rules without allowing incoherency.

P-5. In my opinion the writing studies develop the students' ability of expressing. However while the students are writing they behave reluctant and unwilling. In all class only some students can put their thoughts on paper as a whole. In writing activities they compile their sentences in a short time without planning. Therefore I can see that only minority of the students enjoy while they write essays.

Table 3. The views of the participants about "the applications in the preparation stage"

\begin{tabular}{|c|c|c|c|}
\hline \multirow{2}{*}{ Preparation for writing } & \multicolumn{3}{|c|}{$f$} \\
\hline & Positive & Negative & Total \\
\hline Teaching principles & 9 & - & 9 \\
\hline Motivation & 7 & - & 7 \\
\hline Making the student active & 7 & - & 7 \\
\hline Readiness & 3 & 3 & 6 \\
\hline Teaching strategies and methods & 6 & - & 6 \\
\hline Brainstorming & 5 & - & 5 \\
\hline Mind map & 3 & - & 3 \\
\hline Planning & 3 & - & 3 \\
\hline Association technique & 2 & - & 2 \\
\hline Applicability & - & 2 & 2 \\
\hline Key words & 1 & - & 1 \\
\hline The will for writing & 1 & - & 1 \\
\hline
\end{tabular}

When the views about the applications in the preparation stage are evaluated all of them were positive and the majority of the views were stated about the use of teaching methods. It can be said that the participants consider teaching methods in the studies of determining subject and getting information about the subject in the preparation stage. Among the teaching methods especially the vitality principle was emphasized and it was stated that the subjects that the students encounter are apprehended better accordingly they can be transferred easier. It can be said that the application in the preparation stage activate and motivate the students. Among the teaching methods views were stated mostly about brainstorming and at least about determination of keywords also it was seen that mind map and association were used. However, it was not clear whether this technique was preferred because of its ease of use or it provides the students form their ideas in an easier and faster way. Because there are some other techniques that can be used in the preparation period however none of the participants mentioned these. Besides the views stating that preparation stage increase the readiness of the students, it was stated that this stage could not be applied since the students did not have adequate readiness. This situation was also mentioned in the views stated regarding the applicability issue and it was stated that the students' coming to secondary school without learning artificial language skills make the application of this approach impossible. 
P-3. When we determine the subject to write I benefit from the instructions that take place in the teacher's guidebook. I can limit the subject selection according to the argument. I rarely use free subject choice. I use brainstorming technique in order to reveal students' ideas when we determine the subject. Sometimes I give them a subject and ask them to search. I want them form a text that will enable them share the search results in the classroom.

P-8. The school I work in includes forty four classrooms. I can say that only one of the classes I teach Turkish lessons is successful. The class I mention is $5^{\text {th }}$ grade. While we make a writing study in this classroom we determine the fundamental concepts all together. I make them say the concepts they are supposed to say through discovery method. The other classrooms in the school I work in, cannot read correctly even speak Turkish let alone writing properly.

\begin{tabular}{lccc}
\hline Table 4. The views of the participant about "applications in the planning stage" & & \\
\hline Planning & Positive & Negative & Total \\
\hline Making the student active & 10 & - & 10 \\
Content quality & 8 & 1 & 9 \\
The parts of the text & 8 & 1 & 9 \\
Progressive writing & 7 & - & 7 \\
The attitude towards writing & 4 & 1 & 5 \\
Style quality & 3 & - & 3 \\
Cognitive skills & 3 & - & 3 \\
Aspects of the text & 2 & - & 2 \\
Determining way according to the purpose & 2 & - & 2 \\
Applicability & - & 2 & 2 \\
Style quality & 1 & - & 1 \\
\hline
\end{tabular}

Regarding the applications in the planning stage there were views stated mostly about making the students active and all of the views were positive. It can be said that planning stage supports the students' participating in the writing process actively. Accordingly it can be said that this stage supports learning by experiencing, being motivated to the writing process, interest and willing for writing. Since studies about content are performed mainly in the planning stage, it can be said that planning is important concerning transferring the ideas in en effective and regular way. In this stage determination of the text's parts and the determination of the subjects to be mentioned in every part supports the constitution of a consistent and meaningful text. However, the attempt of the students for limiting the text in three paragraphs, which are introduction, body and conclusion, is a negative state in terms of writing skill and willingness. It can be said that in the planning stage the studies like determining way, text genre and aspects according to the purpose supports the cognitive skills regarding writing acquisition.

P-4. First of all I inform them about the contribution of planning to human life in every aspect. When I'm doing this I give examples from our daily life and daily routine. I tell them practically that the most effective way for listening to the things we write is transferring our emotions and thoughts in a good and planned way. For this I read sample texts. Afterwards I make them write and apprehend the importance of planning.

P-5. In the process of writing mostly we determine the subject we chose together and the under titles it associates through question-answer method. However the students have the most difficulty in the introduction of the text. In the beginning of the essay usually definition sentences take place. In the body of the text only one paragraph is written and sentences that narrate the subject in a limited perspective take place. In the conclusion part the students write the main idea they want to give with a few sentences.

Table 5. The views of the participants regarding "the applications of developing and making the ideas explicit"

\begin{tabular}{lccc}
\hline Developing & Positive & $\begin{array}{c}f \\
\text { Negative }\end{array}$ & Total \\
\hline Content quality & 7 & 4 & 11 \\
Making the students active & 11 & - & 11 \\
The attitude towards writing & 9 & - & 9 \\
Teaching principles & 5 & - & 5
\end{tabular}


Table 5. The views of the participants regarding "the applications of developing and making the ideas explicit"

\begin{tabular}{lccc}
\hline Developing & Positive & $\begin{array}{c}f \\
\text { Negative }\end{array}$ & Total \\
\hline Readiness & 2 & 2 & 4 \\
Informing about the subject & 4 & - & 4 \\
Cognitive skills & 3 & - & 3 \\
Multi assessment and evaluation & 3 & - & 3 \\
Transferring the ideas & 2 & - & 2 \\
Applicability & - & 2 & 2 \\
Writing skill development & 2 & - & 2 \\
Time & 1 & 1 & 1 \\
Style quality & - & 1 & 2 \\
\hline
\end{tabular}

The participants' views mostly focus on content (negative) and making the student active (positive). While it was stated that developing stage increase the content quality; also it was expressed that students' prior knowledge being deficient and since they do not use high level skills and idea developing ways the content cannot be developed. Making the ideas explicit and developed may affect the attitude towards writing in a positive way. It can be said that development stage requires teaching principles, cognitive skills and multi assessment and evaluation method and support writing skills. On the other hand in the development stage it increases the readiness of the students completing preparation and the planning stages. However the student, who does not complete the former stages, passes to this stage without the necessary information and experience. It can be said that this situation not only affects the writing development in a negative way and causes loss of motivation as well.

P-2. I want them to revise the items they form and determine the items about the subject, and eliminate the items that less related to the subject or those that do not relate at all. When they are developing the subject if they cannot find many ideas I give them cases and talk about my observations. In addition I ask them to make observations about the subject and to make a detailed research if there is a deficiency about the subject.

P-8. I am trying to help my students giving them examples from daily life. I put the people and the situations that occupy their lives and they often use in the centre of the idea that I will determine. Using the principle of from known to the unknown from close to the further I am trying to obtain productivity.

Table 6. The views of the participants regarding "the applications in the correcting stage"

\begin{tabular}{|c|c|c|c|}
\hline Correcting & Positive & $\begin{array}{c}f \\
\text { Negative }\end{array}$ & Total \\
\hline Multi assessment and evaluation & 18 & - & 18 \\
\hline Making the active & 10 & - & 10 \\
\hline Content quality & 8 & 1 & 9 \\
\hline Correcting and learning & 8 & - & 8 \\
\hline Cognitive skills & 7 & - & 7 \\
\hline Recognizing the mistakes & 7 & - & 7 \\
\hline Style quality & 5 & 1 & 6 \\
\hline Writing skills development & 6 & - & 6 \\
\hline The attitude towards writing & 4 & 1 & 5 \\
\hline Readiness & - & 3 & 3 \\
\hline Respect aspects & 1 & 1 & 2 \\
\hline Model forming & 1 & - & 1 \\
\hline Applicability & - & 1 & 1 \\
\hline
\end{tabular}

Concerning the studies in the correcting part of the PBWA the participants stated views mostly about multi assessment and evaluation, all of which were positive. The approach of multi assessment and evaluation; includes abstract, peer and teacher evaluations and suggests a process based evaluation. This situation provides opportunity for students to participate in the assessment and evaluation process together with the teachers in the correcting stage, the evaluation of the students' success in every aspect and revealing the students' mistakes. The applications in the correcting stage provide the active participation of the students in the writing process and develop positive 
attitude towards writing. The views focus on the fact that developing stage increases the style and the content quality. Although there were few views stated in the stages of preparation, planning and developing, especially regarding the style quality; the increase in the view frequency reflects that the approach was carried out correctly. Because the studies regarding the style quality on the purpose of making the text written ready for presentation, are carried out in the correcting stage, which is the former stage before publication. However focusing on stylistic rules more than necessary may affect the attitude towards writing in a negative way. The peer evaluation, which provides the students to interact each other in the writing process, is important in terms of teaching being respectful to other people's views. However breaking the rules of respect may create e negative situation. It can be said that the applications carried out in the correcting stage provide the students' recognize and correct their mistakes and affect their cognitive development in a positive way. Thus fulfilling the deficiency of the students, effective and permanent learning is provided and their writing skills development is supported. Concerning readiness it can be said that there were problems resulting from the students, who did not learn how to write and did not perform the former stages as necessary.

P-3. For narrating firstly I want the students to evaluate themselves. Sometimes I use ready pre-assessment forms. Thus I provide awareness in the students. Rather than learning the mistakes recognising the mistake and correcting it is more useful for not repeating it. I ask them to read the essay loudly for a few times by this way the peers can determine the expressions that sound rough. This decreases the similar mistakes of other students.

P-12. Since we start writing with a plan firstly they prepare the plan. I survey their plans one by one. Generally the subject and the topic and the main idea are not separated or they can be independent from each other. Based on the mistake made, I explain the topic again individually. When we agree that everybody's plan is correct we all pass to the body of the essay. We proceed part by part like this correcting. They recognize their mistakes accurately and they make fewer mistakes in the later parts.

Table 7. The views of the participants regarding "the behaviours of the students in the publication stage"

\begin{tabular}{|c|c|c|c|}
\hline \multirow{2}{*}{ Publication } & \multicolumn{3}{|c|}{$f$} \\
\hline & Positive & Negative & Total \\
\hline The will for sharing & 10 & 4 & 14 \\
\hline Self-confidence & 7 & 6 & 13 \\
\hline The attitude towards writing & 8 & 4 & 12 \\
\hline Feedback & 8 & - & 8 \\
\hline Cognitive skills & 3 & - & 3 \\
\hline Fundamental language skills & 3 & - & 3 \\
\hline Writing skills development & 3 & - & 3 \\
\hline Applicability & - & 2 & 2 \\
\hline
\end{tabular}

The participants stated views mostly abut the will for writing regarding the attitudes and reactions of the students in the publication stage. Most of the participants' views about this issue state that the publication stage supports the will of the students for writing and the students want to share the texts they write. However some students who do not want others to see what they write for various reasons creates a negative situation for this stage. It can be said that in the publication stage the students mostly have self-confidence problems and this situation makes the application of the PBWA. Nevertheless the positive views stated regarding self-confidence reflect that this stage affect the students self-confidence in a positive way. With reference to the findings it can be said that the publication stage increases the will of the students for writing and support them develop positive attitude towards writing. It is stated that as a result of publishing the writing of the students they expected positive feedback from their environment and as a result of the feedback they took they indicated will for writing again and publishing. It can be said that publication stage has positive reflections on cognitive, writing and fundamental skills of the students. However it can be said that because of either the reactions of the students or they possess inadequate writing skills there were problem in the applicability of this stage.

P-8. I perform publication stage using the classroom board. When I say that I will put the texts they write on the board nobody agrees. They all object. I have difficulty at this stage. I cannot make sense why they do not want me to put the texts they read comfortably to their friends on the board. A material, which belongs to them, to be on the wall where everybody can see and examine again and again bothers my students. 
P-13. Students, who have a product that belongs to them, become very happy. It is also a good stimulation for being appreciated, accepted and developing themselves. Generally in later stages I see that the students, whose texts are published, are working hard in order to develop their writing skills. They become good examples for their friends.

Table 8. The views of the participants about "the problems encountered in the application of the PBWA"

\begin{tabular}{llll}
\hline Application & $f$ & & Total \\
\hline Time & Positive & Negative & 17 \\
Writing stages & - & 17 & 11 \\
Readiness & - & 11 & 10 \\
Applicability & - & 10 & 8 \\
Content quality & - & 8 & 5 \\
The attitude towards writing & - & 5 & 5 \\
Writing skills development & - & 5 & 4 \\
Writing process & 1 & 3 & 4 \\
Style quality & - & 4 & 1 \\
Feedback & - & 1 & 1 \\
Imaginary world & - & 1 & 1 \\
The difficulty of writing skill & - & 1 & 1 \\
\hline
\end{tabular}

It is seen that the views regarding the difficulties encountered in the application of PBWA focus on time issue and the most of the negative views were stated about this issue. Due to the fact that this approach contains long acting writing applications, it can be said that more lesson period are needed. The participants stated that since PBWA generally takes long time, the students were distracted from the writing process, lesson hours were not adequate and since it requires a long process the studies performed in this approach were inadequate $\mathrm{n}$ number. The views regarding the writing stages assert that it affects the applicability in a negative way. They stated that the students did not have adequate readiness, could not complete the education of reading and writing and could not provide readiness with preparation studies they had serious problems regarding applicability. At this point the biggest problem encountered is the fact that the skills that must be taught in primary school are not acquired. Considering the overall of the research it is remarked that in every question the participants stated views about applicability and these views were negative. This situation reflects that the participants had serious difficulties with applying PBWA and they could not apply it adequately. In this respect the only positive views was given about writing skills development. Although the participants thought that applying PBWA developed the writing skills, they stated they this approach was deficient in turning what is learned into skill. The negative attitude of the students towards writing, some applications in the writing process and the difficulty of providing content quality affect the applicability of PBWA.

P-1. Dealing with the writing studies of the students individually causes spending much time. Teacher's examining all students' writings, talking about some paragraphs and asking what the writer meant there is a time consuming situation. In addition in the determination of the topic and the concepts of the text to be written since the views of the students are taken -not all of them some of them though- showing too much attention for the topic and the will for writing what they say on the board all the time is encountered.

P-7. It is model which requires patience and labour. The process in practice and the application process may be different. This proves that every student can move forward independently. That is to say considering the fact that there are still adult students who cannot read and write we can say that even in this model the result expected is not accessed yet. I still have illiterate students and this is a situation which requires patience not only for them but also for those who are literate.

Table 9. The views of the participants about "the effect of PBWA towards literature and writing"

\begin{tabular}{lccc}
\hline Writing attitude & Positive & $\begin{array}{c}f \\
\text { Negative }\end{array}$ & Total \\
\hline The attitude towards writing & 27 & 1 & 28 \\
Writing skills development & 13 & - & 13 \\
Self-confidence & 6 & - & 6
\end{tabular}


Table 9. The views of the participants about "the effect of PBWA towards literature and writing"

\begin{tabular}{lccc}
\hline Writing attitude & Positive & $\begin{array}{c}f \\
\text { Negative }\end{array}$ & Total \\
\hline Applicability & 1 & 4 & 5 \\
Multi assessment and evaluation & 5 & - & 5 \\
Progressive writing & 2 & - & 2 \\
Making the students active & 2 & - & 2 \\
Fundamental language skills & 2 & - & 2 \\
\hline
\end{tabular}

According to the views of the participants PBWA affects the students' attitude towards writing in a positive way. From this point of view it can be said that PBWA supports self-confidence and writing skill development; this situation reflects their attitude towards writing in a positive way. It can be said that PBWA provide the students write in a stage way and enable them participate in the process with multi assessment and evaluation approach. In addition since they affect each other at the developmental point of fundamental language skills, it is seen that this approach is not limited with providing the development of writing skills. Accordingly all these positive features reflect positively to the approach towards writing. There were negative views only at the point of applicability. This situation can be indicated as sign of that the difficulties encountered during the application of the PBWA, reflect negatively to the students' attitudes towards writing.

P-6. I observe them start writing more consciously and they can reflect the features that belong to the genre and they try to explicit the ideas that they want to assert. The students become happy when they create a text. When there are texts in the sharing stage they become happier. Another point I noticed when I say we will do it most of the students do not act negatively.

P-10. The students always have phobia for writing. What really matters is to destroy this fear. They understand that the writing can be elaborated with the content rather than the beauty of the letters. In order to write better they enjoy using proverbs, idioms and aphorisms to support their content with such sayings. At the end of every text they see themselves as a merely famous writer.

Table 10. The views of the participants about "process based assessment and evaluation the applications"

\begin{tabular}{lccc}
\hline Assessment and evaluation & Positive & $\begin{array}{c}f \\
\text { Negative }\end{array}$ & Total \\
\hline Writing skills development & 13 & - & 13 \\
Analytic evaluation & 9 & - & 9 \\
Making the student active & 6 & - & 6 \\
Process based evaluation & 6 & - & 6 \\
The attitude towards writing & 5 & - & 5 \\
Multi assessment and evaluation & 3 & - & 3 \\
Personal development & 3 & - & 3 \\
Cognitive skills & 2 & - & 2 \\
Applicability & - & 2 & 2 \\
\hline
\end{tabular}

The measurements and evaluations used in the STYY support the holistic development of the student by providing active participation. It is seen that this approach contains multi assessment and evaluation, analytic evaluation and process based evaluation styles. Analytic evaluation provides evaluation from every aspect separating sub-branches like style, content and the use of language. Multi assessment and evaluation provides the teacher and the students participate in the evaluation process together. Process based evaluation supports these two types of evaluation and evaluates the activities of students in the writing process more. Since PBWA contains all these evaluation structures, it provides the students participate in the writing process actively and affect their attitude towards writing in a positive way. It can be said that the applicability of the assessments and evaluations that PBWA contains is difficult in terms of teachers. This situation may result from the fact that the teachers need to give feedback checking all students and at the point of peer evaluation the respect aspects are passed over.

P-7. I often consult peer evaluation. The things that the teacher overlooks do not escape the attention of the students. And also when the students feel that they are an individual in the classroom they learn to respect their 
own and others ideas. By this way they do not shy away from expressing their thoughts and they lay down their existence.

P-13. In written expression assessment is aimed at whether the standard expected in other words the progress is developed or not. Question such as whether what is expected from the basic rules of Turkish language is given or not, is the arrangement and order is provided, are the spelling and orthographic rules obeyed, is it the expected size, does it have the appropriate headline, is the introduction beginning with general expressions, is the body developed using event patterns, are the ways to develop the main idea used in an appropriate way, are formed and I examine together with the students and evaluate.

Table 11. The views and suggestions of the participants about PBWA

\begin{tabular}{|c|c|c|c|}
\hline \multirow{2}{*}{ Views and suggestions } & \multicolumn{3}{|c|}{$f$} \\
\hline & Positive & Negative & Total \\
\hline Applicability & - & 10 & 10 \\
\hline Writing skills development & 9 & - & 9 \\
\hline Readiness & - & 8 & 8 \\
\hline Writing process & 4 & 1 & 5 \\
\hline The attitude towards writing & 2 & 3 & 5 \\
\hline Making the students active & 3 & - & 3 \\
\hline Cognitive skills & 2 & - & 2 \\
\hline Multi assessment and evaluation & - & 2 & 2 \\
\hline Holistic development & 1 & - & 1 \\
\hline Self-confidence & - & 1 & 1 \\
\hline
\end{tabular}

Considering the ideas that the participants wanted to state other than the questions asked about PBWA it is seen that the most views focus on at the point of applicability. All of the ideas stated on this issue being negative is the reflection of the participants' cannot apply PBWA exactly. The participants needed to express the difficulties they had at the point of applying once again. It was stated that the PBWA was affected negatively by the problems encountered concerning environment and classroom atmosphere, student levels, lesson hour and time issues. In addition to all the problems these factors cause the inadequacy of the teachers might reflect to the applicability as well. Nevertheless the findings obtained indicate that PBWA support students' writing skills development, cognitive and holistic development in a positive way. Also it can be remarked that this approach makes the student active and affect the writing process positively. The students' being inadequate in terms of readiness may result from the fact that they did not make up their deficiencies getting enough information in the preparation stage. The students' negative attitudes resulting from generally being diffident, prejudiced and anxious towards writing may increase in the processes of publication and evaluation because of mistakes and deficiencies regarding applying. The self-confidence of the children, who compare their writing with their friends or who take negative criticism, may be affected negatively. Considering all these positive and negative evaluations together it can be stated that when PBWA is applied correctly and effectively it supports cognitive, emotional, psychomotor and personal developments in addition to writing skills and attitudes towards writing. However because of the difficulties, deficiencies and inadequacies encountered concerning applying, it can be said that the writing attitudes, writing process and self-confidence of the students were affected negatively.

K-1. I think process based writing studies are better for the students only compared to product based writing studies. In this approach the students learn that the writing is performed step by step and how they must be careful in every stage. In the classical writing method the students, who do their task unsociably, socialize in the process based writing approach.

K-11. I cannot perform this method in class. Moreover I cannot utilize most of the data of the constructivist system. The prior knowledge of my students is very inadequate. Their financial state of their family is very bad. Their families do not take care of their kids. Probably since their teachers in the primary school could not give close attention and support to the children I have big problems in this process. I am trying to do my best.

\section{Discussion and Conclusion}

The views of the participants concerning the contribution of PBWA to the writing skills; focus on the fact that it affects the students' attitude towards writing, writing skills, cognitive and personal development, fundamental 
language skills positively. None the less it was stated that there were problems concerning time and applicability. PBWA's turning writing transaction into a series of stages provides convenience for the teacher and the students in terms of proceeding applying the information and the skills properly (Badger \& White, 2000). In an experimental pattern research it was determined that PBWA affects the students' attitude towards writing, their writing habits and skills in appositive way (Ho, 2006). It was determined that in addition to contributing to essay writing skills this approach provides active participation of the students and affect their self-confidence and desire for writing positively (Y1lmaz \& Aklar, 2015). It was determined that compared to product based approach PBWA develops writing skills of the students more (Zhou, 2015). In another experimental research it was determined that this approach contributes to the students' creative writing skills development (Sever, 2013). Most of the researches carried out indicate that PBWA affect the students' written expression skills positively (Balc1, 2017; Karatosun, 2014; Sever, 2013; Şentürk, 2009). The findings of the research are supported in this respect.

As a result of the analysis of the views regarding the preparation stage it can be said that the application in this stage affects the students' active participation, motivation and desire for writing positively. In addition it was emphasized that the students could not provide readiness for the next stages when they could not evaluate this stage adequately, also the skills that must be acquired in primary school were not gained and this stage took long time. It was determined that the writing acquisition of the individual must be considered as a process and it must be performed, this process must be performed starting from first reading and writing education and as long as development is provided teaching new acquisitions will be right (Okari, 2016). Most of the writing activities performed in the writing process are preparation purpose and it was stated that their preparation support assessment and evaluation applications (Storch, 2005). It was determined that planned writing and evaluation model give the students the opportunity to make more plans and generate ideas sparing $70 \%$ of the writing process for them (Y1lmaz, 2012). From this point of view in terms of applying PBWA the preparation stage is a vital stage, which must be applied properly and completely. The importance of the preparation stage must be taught to students and they must be enabled to perform this stage completely. On this issue activities that will keep the students' attention and desire alive, motivate and provide them participate in the process actively and these activities must be moved to the educational environments and classrooms.

It can be said that the applications in the planning stage generally contribute to the content and style quality of the text, determining way according to the purpose, and for the determination of the factors and parts of the text. In addition it was determined that there were views stating that this stage contribute to the students' being active, their positive writing attitude, stage writing and cognitive skills. However it was stated that there were problems encountered concerning applicability. At this stage forming a writing draft the messages desired to be given can be transferred to the target group in a more effective way. (Reimer, 2001). In a research carried out on this matter it was determined that the people whose writing habits and success is low do not form a good plan and they have deficient planning skills (Jensen \& DiTiberio, 1984). PBWA, which is based on systematic planning process, support cognitive awareness of the students and the content quality of the text; and arrange teacher-student relation and the learning process (Johari, 2018; Duman, 2007). The results obtained in the research support the results of the studies performed in the field. From this point of view it can be said that planning skill support writing skills in many aspects.

It was determined that there were views stating that the developing stage provide students' active participation, develop positive attitude towards writing, development of cognitive and writing skill and the transfer ideas. However in accordance with the views it was stated that there were problems encountered concerning the style quality and applicability. The researches carried out support the positive side of the results obtained. PBWA support writing skills development through the transactions of rereading the writings, questioning, evaluation and revision (Zare-ee \& Mahdavi, 2014). At this stage the teacher's feedback and the use of peer evaluations affect the quality of the text and the writing skills in a positive way (Tuan, 2011). The developing stage; not only provides the students interact each other but enable cooperation and communication as well (Storch, 2005). Studies like forming a writing draft, arranging ideas and revision increase cognitive awareness and support writing strategies (Karatay, 2011). In this direction it can be said that process based approach support writing skills and cognitive skills. In the developing stage writing the ideas correctly and effectively is emphasized more (Seow, 2002). However in this stage forcing the students about the rules of spelling, orthography and grammar will cause various problems. Accordingly it can be said that applying PBWA incorrectly underlies in the negative views determined regarding style quality. In the researches carried out in the field the reason why a similar result was not obtained statistically may result from this. 
The correction stage; contribute to the students' writing skills, attitude towards writing, recognizing and correcting their mistakes and to the content and style quality of the text in terms of providing opportunity for the use of multi assessment and evaluation approach. However it was stated that in the process of peer evaluation sometimes respect aspects were ignored, so teachers must be careful about this issue. In addition it was stated that there were problems due to the fact that the students did not evaluate the previous stages adequately and the skills that must be gained in primary school were not acquired. In the experimental research carried out about this issue there was a positive significant difference found about the issues of manner, content, grammar, spelling and punctuation (Kallestinova, 2017). It was determined that the students, who perform process based writing applications, make progress in terms of act of writing, manner, fluency, word choice and presentation features (Görgüç, 2016). It can be said that the assessment and evaluation applications that the correcting stage requires contribute to producing qualified texts in terms of writing skills, style and content.

As a result of the analysis of the views regarding publication stage, it can be said that this stage affects students' desire to share, their self-confidence, attitude towards writing, cognitive, fundamental language and writing skills in a positive way. However the students' anxiety for writing, their prejudices, lack of self-confidence and the problems concerning the applicability pose negativity for this stage. The publication stage provides students focus on correcting stage, forming the content and style quality of the text, and make tiny distinctions about meeting the requests of the reader (Kallestinova, 2017). It was determined that the publication stage affect the students' writing attitude and self-confidence positively (Selanikli, 2015).

As a result of the analysis of the participants' views regarding the applicability of PBWA, it was claimed that the approach stages, lack of time, deficiency of readiness and imaginary world, focusing on style and content quality affect the applicability of the subjects. It was determined that regarding writing education the teachers mostly had problems concerning lack of time, excessive number of the students in the classroom, lack of education (Krendl \& Dodd, 1987). In order to eliminate the time problem encountered in the PBWA application, writing classes can be added or the number of Turkish language classes can be increased. For teachers in order to take care of all students and give feedback the number of the students in the classroom must be decreased. All the negative aspects stated not only reflect to the applicability of the approach but to the students' writing skills as well. The teachers must make tiny distinctions about applying PBWA correctly and completely. Especially the rules of act of writing, punctuation and grammar should not be forced to the students, the writing attitude of the students must be cared and the communicational competence must be centred. It is known that the students have problems in applying the feedback of the teachers and expressing themselves correctly because of vocabulary and grammar knowledge deficiency (Zhou, 2015). It can be said that in the applying of the approach this situation has negative reflections. In the sub-problems of the research views regarding various problems encountered in the applying of the approach were determined.

There are some views regarding PBWA affects the students' attitude towards literature and writing in a positive way. The participants' views regarding this issue state that this model increases the students' active participation in the class, their self-confidence, fundamental language and writing skills. Within the researches carried out concerning this issue on university students it was determined that PBWA decreases the anxiety of the students for writing and increase their writing success (Bayat, 2014; Ho, 2006). It was stated that his approach increased the desire of the students for writing (Duijnhouwer, Prins, \& Stokking, 2012; Mehr, 2017; Reimer, 2001; Zhou, 2015). PBWA increase the students' writing self-efficacies, and their attention and desire and also support them develop positive attitude towards writing (Hamid, 2017). In addition, it was stated that PBWA motivated the students who cannot write (Y1lmaz, 2012). Within this research, which was carried out with experimental method, it was concluded that process based creative writing applications affected the writing attitude and skills of the students positively (Erdoğan \& Yangın, 2014). It was determined that PBWA affected the attitude towards writing positively (Balc1, 2017; Görgüç, 2016). Nevertheless there are researches stating that this approach does not affect the writing attitudes of the students (Selanikli, 2015; Aksu \& Karatay, 2017). This situation may be resulting from the sample group utilized in the research. Because many studies in the field concluded that PBWA affected the writing attitude positively.

Process evaluation beyond the determination of the rate of possessing aimed acquisitions with the activities performed in the learning process, aims making the learning better and the development of cognitive, emotional and psychomotor skills as a whole (Göçer, 2014). It can be said that the assessment and evaluation used in PBWA reached this goal. It can be said that the assessment and evaluation tools used in the process based writing applications affect writing skills and cognitive skills positively and make the students active. However the views 
stating that the teachers had difficulties at the point of giving feedback to all students and providing a democratic classroom during the assessment and evaluation applications were determined. In a research carried out with experimental method it was concluded that the teachers' giving feedback increased the self-confidence, writing performance and motivations of the students (Duijnhouwer, Prins, \& Stokking, 2012). The feedback taken from the teacher and the peers affect the writing process, motivation and performance positively (Reimer, 2001; Zhou, 2015). In addition it is known that peer feedback contribute to the students' metacognitive awareness and development of the language skills (Nguyen, 2016). On the other hand it was asserted that during peer evaluation the students feel worried about being criticized and they have self-confidence and anxiety problems (Storch, 2005). With all positive and negative aspects all these researches empower the result concluded.

It was stated that the readiness and self-confidence deficiency of the students; the assessment and evaluation applications of the approach affect the writing skills and the process based writing applications negatively. However there were views stated that this approach contributes in terms of extending the writing transaction in a process, making the students active and providing writing development beside holistic development. In a research carried out with experimental method it was stated that PBWA contributed to the writing success and habits, selfconfidence and developing positive attitude towards writing (Özenç, 2016). For the development of writing skills and writing success PBWA must be used (Jensen \& DiTiberio, 1984). It was asserted that PBWA supports the writing motivation of the students and their capability of writing a qualified text (Graham \& Sandmel, 2011). The researches in literature agree on the view that process based writing applications contribute to the writing skills development and support the findings of the research.

\section{Acknowledgement}

This study was formed with reference to the master degree seminar named "Teacher Opinions on the Applicability of the Process Based Writing Approach". I would like to express my gratitude to my dear advisor Assist. Prof. Dr. Sezgin DEMIR, who guided and mentored me with his knowledge and experience and also supported me in every stage of the research process. In addition this research was presented as verbal announcement in $\mathrm{V}^{\text {th }}$ EJER Congress, which was performed in Antalya, on 2-5 May 2018. 


\section{Süreç Temelli Yazma Yaklaşımının Uygulanabilirliğine İlişkin Öğretmen Görüşleri}

\section{Giriş}

İnsana özgü bir iletişim aracı olan yazma, içerdiği süreçler bakımından diğer temel dil becerilerine göre daha fazla zihinsel ve fiziksel aktivite gerektiren zorlu bir dil becerisidir. Konuşmadan daha farklı işlemler gerektiren yazma, konuşmadan daha zor görünse de kazanılamayacak bir beceri değildir (Şahin, 2007). En son kazanılan dil becerisi olması ve gelişiminin en son tamamlanması, yazma becerisinin zor olarak görülmesinin nedenlerindendir. Buna ek olarak düşünce, hayal dünyası, kelime hazinesi gelişimi gibi birikimler ve bir dizi hazırlık (konu, tür, amaç vb. belirlenmesi) gerektirmektedir (S. Maden, Dincel, A. Maden, 2015). Yazma sırasında, fikirlerin zihinde oluşumuyla somutlaştırma aracı olan ele kadar devam eden zorlu süreç, durumu destekler niteliktedir.

Yazma becerisi bireyin, zihinsel, duyuşsal ve devinsel yönlerden gelişimini desteklemektedir. Yazma öğrenme alanı, temel bilgi ve becerilerin kullanılabilecek düzeyde elde edilmesi ile kazanılan bu unsurların yazılı anlatım sırasında nasıl kullanılacağının öğrenilmesi olmak üzere iki ayrı aşamada gerçekleşmektedir (Gömleksiz, Sinan \& Demir, 2010). Yazma sırasında kullanılan inceleme, gözden geçirme, sorgulama, ilişkilendirme, kontrol etme gibi zihinsel işlemler zihin yapısını düzenlemekte ve çok sayıda zihin becerisini geliştirmektedir (Güneş, 2007). Oysa davranışçı yaklaşımın geliştirdiği ürün temelli yazma yaklaşımı, düşüncelerin belli kurallara göre kâğıda aktarılmasından ibarettir (Sezgin, 2016). Bu yöntem öğrencileri birtakım kurallarla sıkıştırarak özgün ve yaratıcı metinler üretebilme becerilerini ve yazma tutumlarını olumsuz yönde etkilemektedir. Ürün temelli yazma yaklaşımı pek başarılı görülmediği için yapılandırmacılığın uygulanmaya başlamasıyla birlikte terk edilmiştir.

Davranışçılığın aksine yapılandırmacı yaklaşım; öğrenciyi aktif kılmakta; sonuca değil, sürece odaklı bir anlayışı benimseyerek öğrenciye eleştirel düşünme, sorgulama, karşılaştırma vb. becerileri kazandırabilmeyi hedeflemektedir (Gömleksiz, Sinan \& Demir, 2011). Eğitimde yapılandırmacı yaklaşımın benimsenmeye başlanmasıyla yazma eğitiminde de süreç temelli yazma yaklaşımı (STYY) uygulanmaya başlanmıştır. Bu yaklaşım, planların yaygın ve sürekli kullanılmasını içerdiğinden bilgiyi edinmek, yapılandırmak, geliştirmek, davranışları düzenlemek, iyileştirmek amacıyla kullanılmakta ve öğrencilerin bilgiyi aktarırken süreci düzenleyerek her aşamada bilişsel farkındalık sahibi olmalarını öngörmektedir (Karatay, 2011). STYY'de; öğretmenler, öğrencilerin yazdıklarına geri dönütler ve değerlendirmeler yaparak, öğrencilere olumlu yönlendirmeler yapabilmektedirler. Ayrıca bu yaklaşım, öğrencilerin yazma sürecini adım adım yöneterek kendilerini değerlendirmelerine, yanlışlarını düzeltmelerine firsat sağlamakta; düşüncelerini geliştirerek yazı kalitelerini olumlu yönde etkilemekte ve öz güvenlerini destekleyerek yazmaya karşı isteklerini artırmaktadır.

STYY, yazmayı bir noktadan başlayan belirli aşamalar dizisi olarak, öğretmeni ise öğrencilerin bilgi ve becerilerinin gelişimini sağlayan bir yol gösterici olarak görür (Badger \& White, 2000). Bu yaklaşım, metnin sürekli gözden geçirilerek geliştirilmesine odaklanır, buna bağlı olarak öğretmenlerden ve akranlardan sürekli geri bildirim alınır (Nordin, 2017). Geri bildirimler içerik, üslup, yazım ve noktalama gibi metnin bütün yönlerini kapsamaktadır. Bu yönüyle geleneksel yazma yaklaşımının hedeflediği dil kurallarını da önemsemekte; ancak bunu bir temel amaç olarak değil, yazma becerisini geliştirme yolunda bir araç olarak görmektedir. Öğrenciler bilgi eksikliği yaşadığında ise üç kaynaktan yararlanır; öğretmen, diğer öğrenciler ve örnek metinler (Badger \& White, 2000). Öğretmen ve öğrencilerin sürekli etkileşim içinde bulunduğu bir ortam, bilgi ve becerilerin daha aktif hâle gelmesine, daha iyi sindirilmesine olanak sağlar. Ayrıca örnek metinlerden yararlanılması çocukların dil gelişimi, kelime dağarcığı ve yazma becerileri için önemlidir. Sunulan örnek metinler geleneksel yaklaşımdaki gibi öğrencinin taklit etmesi için değil, ön bilgilerini artırması içindir.

STYY, öğrencilere yazma becerilerini nasıl kullanacaklarını öğretmeyi ve yazma becerilerini geliştirmeyi amaçlayan, kuru bilgi öğreniminden çok, bilginin kullanımına yoğunlaşarak bilginin zihinde yapılanmasını ve özümsenmesini temel alan bir öğretim yoludur. Bu yaklaşımda öğrencilerin, düşünme sürecine yoğunlaşarak her aşamada bilişsel farkındalığa sahip olmaları, genel olarak yazma sürecini düzenlemeleri gerektiğini vurgulayan Karatay (2014), bu yolla karar verme, bağımsız düşünme, analiz, sentez, problem çözme, öğrenmeyi öğrenme gibi becerilerin geliştirildiğini savunmaktadır. Öğrencilere hayal dünyalarında ve fikirlerini ifade etme konusunda özgürce hareket imkânı tanıyan STYY, öğrencilerin yaratıcı ve özgün metin üretmesini sağlayarak onların hem dil gelişimlerine hem de sanatsal ve estetik gelişimlerine katkı sağlamaktadır. Yazarı metnin yaratıcısı olarak gören STYY'nin en önemli bileşenleri yaratma ve üretme sürecidir (Silva, 1990). Tüm bu yararları göz önünde bulundurulduğunda STYY’nin, yazma beceri gelişimi adına uygulanması gerektiği ortadadır. 
STYY konusunda alan yazında yapılan araştırmalar incelendiğinde deneysel modelde çalışılmış tezlerin yoğunlukta olduğu görülmektedir (Aksu, 2015; Erdoğan, 2014; Reimer, 2001; Selanikli, 2015; Sezgin, 2016; Ülper, 2009;). STYY'nin, öğrencilerin yazma becerilerine etkisinin belirlendiği çalışmalar doğrultusunda; 5. sinıf öğrencilerinin kompozisyon yazma becerilerinin gelişimlerine etkisi (Güvercin, 2012), 8. sınıf öğrencilerinin bilgilendirici metin yazma becerilerine etkisi (Şentürk, 2009), 4. sınıf öğrencilerinin yazılı anlatım ve yaratıcı yazma becerilerine etkisi (Sever, 2013) araştırılmış ve hepsinin sonucunda STYY'nin öğrencilerin yazma becerilerine katkıda bulunduğu tespit edilmiş̧ir. $\mathrm{Bu}$ konudaki makalelerin genellikle nicel yöntemle gerçekleştirildiği ve yaklaşımın yazma becerilerine etkisi üzerine yoğunlaşıldığı görülmektedir (Bayat, 2014; Graham \& Sandmel, 2011; Kallestinova, 2017; Johari, 2018; Yılmaz, 2012). Ancak yaklaşımın uygulayıcısı olan öğretmenlerin bu modeli ne kadar benimsediği ve uyguladığı konusu aydınlatılamamıştır. STYY'nin uygulayıcısı olarak ve süreci bir rehber olarak yönlendiren öğretmenlerin konu hakkındaki görüşlerinin belirlenmesi duruma farklı bakış açısı kazandıracağı düşüncesiyle bu araştırma gerçekleştirilmiştir.

\section{Araştırmanın Amacı}

Araştırmanın amacı, STYY’nin uygulanabilirliğine ilişkin Türkçe öğretmenlerinin görüşlerinin belirlenmesidir. Bu genel amaç doğrultusunda; STYY'nin öğrencilerin yazma becerilerine katkısı, hazırlık aşamasında yazı konusunun ve temel kavramların belirlenmesi, planlama aşamasında yazı planının ve bölümlerinin oluşturulması, düşünce planın oluşturulması ve düzeltme aşamasındaki uygulamalar, yayımlama aşamasındaki öğrenci tepki ve davranışları, STYY derste uygulanırken karşılaşılan zorluklar, STYY'den hareketle kullanılan ölçme ve değerlendirme yöntemleri, STYY'nin öğrencilerin yazmaya karşı tutumlarını, yazar olma isteklerini ve edebiyata yönelik ilgilerini ne şekilde etkilediğine ilişkin katılımcıların görüşlerinin belirlenmesi amaçlanmıştır.

\section{Yöntem}

Nitel araştırma desenlerinden olgubilimsel (fenomenolojik) türde gerçekleştirilen bu araştırmada bire bir görüş̧e yöntemi kullanılmış, verilerin analizinde ise içerik analizi tercih edilmiştir. Görüşme yönteminin kullanıldığı çalışmalar; araştırmacının, güven ve empatiye dayalı görüşmeler yardımıyla bireylerin bir fenomenle ilgili yaşantılarının ortak anlamını betimlediği, felsefe ve psikoloji kaynaklı araştırmalardır (Creswell, 2016b; Creswell, 2016a; Büyüköztürk, Kılıç Çakmak, Akgün, Karadeniz, \& Demirel, 2017). Açık uçlu mülakatlar, doğrudan gözlem ve yazılı doküman çözümlemesi şeklinde üç farklı yönteme sahip olan nitel araştırmalarda; insanların deneyim ve algılarını içerik analiziyle tespit etmek hedeflenir (Patton, 2014).

\section{Çalışma Grubu}

Araştırmanın çalışma gurubu amaçlı örnekleme yöntemiyle belirlenmiş, hedef evren konumundaki tüm Türkiye'deki Türkçe öğretmenlerine ulaşmak mümkün olmadığından ulaşılabilirliği sağlamak amacıyla alt evren olarak Elazığ ili devlet okullarında görev yapan Türkçe öğretmenleri belirlenmiştir. Gönüllülük esası temel alınarak araştırmacılar tarafından yeterli veri toplandığına kanaat getirilene kadar yeni görüşme yapılmaya devam edilmiş ve katılımcılardan yeni görüşler gelmediği kanaatine varıldığında, 14. katılımcı ile yapılan görüşmede çalışma grubu tamamlanmıştır. Görüşme tekniğinin kullanıldığı araştırmalarda, örneklem sayısının büyüklüğü veya küçüklüğü yerine, örneklemin ihtiyaç duyulan bilgi miktarını karşılayıp karşılamadığına bakılır (Türnüklü, 2000). Görüşmelerin gerçekleştirildiği katılımcılara ait bilgiler:

\begin{tabular}{llcc} 
Tablo 1. Katılımcılara ait bilgiler. & & $\mathbf{n}$ & $\mathbf{\%}$ \\
\hline Cinsiyet & Kadın & 9 & 64.29 \\
& Erkek & 5 & 35.71 \\
\hline \multirow{2}{*}{ Eğitim durumu } & Lisans & 13 & 7.14 \\
& Yüksek lisans & 1 & 92.86 \\
Hizmet süresi & Öğretmen & 13 & 7.14 \\
& Uzman öğretmen & 1 & 92.86 \\
\hline
\end{tabular}


Çalışma 2017 yılında devlet okullarında aktif çalışan 9 kadın, 5 erkek olmak üzere toplam 14 Türkçe öğretmeni üzerinden gerçekleştirilmiştir. Bu öğretmenlerden yalnızca 1'i uzman öğretmen, 1'in yüksek lisans mezunu iken 6 öğretmen 6 yll ve üstü hizmet süresine sahiptir.

\section{Veri Toplama Araçları}

Araştırmacılar tarafından geliştirilmiş, yarı yapılandırılmış 10 sorudan oluşan görüşme formu veri toplama aracı olarak kullanılmıştır. Alan yazından hareketle hazırlanan taslak form, aktif çalışan 5 Türkçe öğretmeninin görüş ve değerlendirmelerine sunulmuştur. Ardından kapsam geçerliği için Firat ve Nevşehir Hacı Bektaş Veli üniversiteleri Türkçe eğitimi ana bilim dallarında görev yapan öğretim üyelerinin görüşleri alınmış ve bu doğrultuda gerekli düzeltmeler yapılarak görüşme formuna son şekli verilmiştir. Katılımcıların düşünce, tutum ve davranışlarıyla bunların olası nedenlerinin öğrenilmesi için (Karasar, 2009) gerçekleştirilen bire bir görüşmeler sonucunda elde edilen veriler kayıt altına alınmıştır. Katılımcıları bağımsız düşündürebilmek maksadıyla açık uçlu sorulardan yararlanılmış, gerektiğinde ek sorular sorularak yarı yapılandırılmış görüşmeler gerçekleştirilmiştir.

\section{Verilerin Toplanması ve Analizi}

Veriler bilgisayarda yazılı hâle getirildikten sonra katılımcılara kontrol ettirilerek araştırmanın "inandırıcıllı̆ı", çalışma süreci hakkında katılımcılara bilgi verilerek çalışmanın "aktarılabilirliği" sağlanmaya çalışılmıştır. Elde edilen görüşme verileri, içerik analiz yöntemi kullanılarak analiz edilmiştir. Veri analizi; verileri kodlamayı, her birime etiketler atamayı ve katılımcıların veya araştırmacının ifadelerinden, sosyal ya da beşeri bilimlerde kullanılan kavramlardan seçilen kodları temalar altında gruplandırmayı içermektedir (Creswell \& Plano Clark, 2015). Katılımcı görüşlerine yönelik oluşturulan kategoriler alan yazından hareketle katılımcı görüşleri temel alınarak oluşturulup "kategori netliği”" sağlanmaya çalışılmıştır. Çalışmada benzer cevaplar bir araya getirilerek cevapların toplam cevaplar içindeki frekansları tablolaştırılmış ve frekanslar tabloların altında yorumlanmıştır. Nitel araştırmalarda kodlayıcı güvenirliği, farklı kodlayıcıların aynı metni aynı şekilde veya aynı kodlayıcının metni farklı zamanlarda aynı şekilde kodlamasıyken kategori güvenirliği kategorilerin açık ve net olmasıdır (Bilgin, 2014; Sönmez ve Alacapınar, 2016). Bu araştırmada veriler, aynı kodlayıcı tarafindan farklı zamanlarda iki kez kodlanarak analiz edilmiş, kodlamalar arasındaki uyumun ilk etapta $\% 70$ 'in üzerinde çıkması hedeflenmiştir. Bu sayede "kodlayıcı güvenirliği" sağlanması amaçlanmış, her katılımcıyla yapılan görüşmeden sonra kodlamalar gerçekleştirilmiş ve sonraki katılımcıyla yapılan görüşme için hazırlık yapılmıştır (Miles \& Huberman, 2016). Kodlayıcı güvenirliğinin sağlanması için Miles ve Huberman'ın (2016) "Güvenirlik=Görüş Birliği Sayısı/Toplam Görüş Birliği + Görüş Ayrılığı Sayısı” formülünden yararlanılmıştır. Uyum yüzdesinin (Güvenirlik=467/467+172= .73) \%73 olmasından hareketle çalışma, kodlayıcı güvenirliği açısından yeterli bulunmuştur.

\section{Bulgular}

Görüşmelerden elde edilen bulgular, araştırmada yöneltilen ve araştırmanın alt amaçlarını oluşturan sorulara göre bir araya getirilerek alan yazından hareketle yorumlanmıştır.

Tablo 2. Katılımcıların "STYY'nin yazma becerilerine katkısı" hakkında görüşleri

\begin{tabular}{lccc}
\hline STYY'nin yazma becerilerine katkısı & Olumlu & $\begin{array}{c}\text { f } \\
\text { Olumsuz }\end{array}$ & Toplam \\
\hline Düşünceleri aktarabilme & 7 & 3 & 10 \\
Yazmaya yönelik tutum & 6 & 4 & 10 \\
Çoklu ölçme ve değerlendirme & 9 & - & 9 \\
Bilişsel beceriler & 7 & - & 7 \\
Planlama & 6 & 1 & 7 \\
Kişisel gelişim & 6 & - & 6 \\
Ölçünlü dil kullanımı & 4 & 2 & 6 \\
Yapılandırmacı yaklaşım & 6 & - & 5 \\
Hażrlık & 5 & - & 4 \\
Aşamalı yazma & 4 & - & 4 \\
Zaman & 2 & 2 & 2 \\
Uygulanabilirlik & - & 2 & 2 \\
Temel dil becerileri & 2 & - & \\
\hline
\end{tabular}


STYY’nin öğrencilerin yazma becerilerine katkısına yönelik görüşler, en çok düşünceleri aktarabilme ve yazmaya yönelik tutum konularında yoğunlaşmaktadır. Katılımcıların deneyimleri ve gözlemleri, STYY'nin, öğrencilerin düşüncelerini daha etkili ve düzenli bir şekilde kâğıda aktarabilme becerilerini geliştirdiği yönündedir. Ancak yapay dil becerisi olan yazma, birtakım kurallara uymayı gerektirdiği için düşünceleri kâğıda aktarma aşamasında öğrencilerin zorlandıkları ve veri kaybı yaşadıkları belirtilmiştir. Öğrencilerin, yazmaya karşı ön yargı içinde olmaları, yazmaktan kaçmaları, yazma işleminin uzun bir sürece yayılması ve sabır gerektirmesi gibi nedenlerin yazmaya yönelik tutumu olumsuz etkilediği söylenebilir. Çoklu ölçme ve değerlendirmenin kullanılması; öğrencilerin hatalarını görmeleri, arkadaşlarının hatalarından ders çıkarmaları, aldıkları dönütler doğrultusunda kendilerini değerlendirmelerini ve hatalarını düzeltmelerini sağlayarak yazma becerilerinin gelişimlerini destekleyebilmektedir. STYY'nin bilişsel becerilerin etkin kullanımı, planlama becerilerinin gelişimi, kişisel gelişimi, ölçünlü dil kullanımını ve yapılandırmacı öğrenimi desteklemesi yönüyle yazma becerilerini geliştirdiği söylenebilir. Buna karşı öğrencilerin, planlama yapmadan kısa sürede yazma eğilimleri ve ölçünlü dil kullanımının birtakım kurallar gerektirmesi yazma beceri gelişimlerini olumsuz etkilediği yönünde görüşler de belirtilmiştir. Hazırlık aşamasının ve aşamalı yazmanın uygulanması yazma gelişimine katkı sağlarken süreç içinde öğrencilerin okumaya ve sosyalleşmeye yönlendirilmesi temel dil becerilerinin bütün olarak gelişimini de destekleyebilmektedir. Yazma sürecinin zamana yayılması açısından daha fazla düşünmeye ve hayal gücü kullanımına firsat verirken, ders saatinin yetersiz olması ve uzun bir süreç sonunda gelişimin ortaya çıkması yazma becerisini olumsuz etkilemektedir denilebilir. Bu durumun, STYY'nin uygulanabilirliğine olumsuz yansımalarının olduğu ifade edilmiştir.

K-6. Öğrencilerimize yazmadan önce, yazma sırasında ve yazmanın sona ermesi ile üç aşamalı bir yazma modeli öğretiyor. Yazmaya karşı daha bilinçli ve hazırlıklı yapıyor. Süreç temelli yazma yaklaşımı öğrenciye bir metin ortaya koyarken rastgele bir şekilde yazılmayacağını, belli süreçleri takip edeceğini öğretiyor aslında. Ayrıca anlam bozukluğuna yer vermeden noktalama ve yazım kurallarına dikkat etmesi gerektiğini vurguluyor.

K-5. Yazma çalışmalarının öğrencilerin ifade becerilerini geliştirdiğini düşünüyorum. Ancak öğrenciler yazarken isteksiz ve gönülsüz davranıyorlar. Bütün sınıfta yalnızca birkaç öğrenci düşüncelerini bir bütün olarak yazıya dökebiliyor. Yazma etkinliklerinde kısa sürede ve plansız bir şekilde cümlelerini sıralıyorlar. Bu yüzden öğrencilerin yalnızca küçük bir kısmının kompozisyon yazarken keyif aldığını görüyorum.

Tablo 3. Katılımcıların "hazırlık aşamasındaki uygulamaları” hakkında görüşleri

\begin{tabular}{lccc}
\hline Yazmaya hazırlık & Olumlu & Olumsuz & Toplam \\
\hline Öğretim ilkeleri & 9 & - & 9 \\
Güdüleme & 7 & - & 7 \\
Öğrenciyi aktif kılma & 7 & - & 7 \\
Hazırbulunuşluk & 3 & 3 & 6 \\
Öğretim stratejileri ve yöntemleri & 6 & - & 6 \\
Beyin firtınası & 5 & - & 5 \\
Kavram haritası & 3 & - & 3 \\
Planlama & 3 & - & 3 \\
Çağrışım tekniği & 2 & - & 2 \\
Uygulanabilirlik & - & 2 & 1 \\
Anahtar kelimeler & 1 & - & 1 \\
Yazma isteği & 1 & - & \\
\hline
\end{tabular}

Hazırlık aşamasındaki uygulamalar hakkındaki görüşler değerlendirildiğinde hepsi olumlu olmak üzere en çok görüş, öğretim ilkelerinin kullanımı konusunda belirtilmiştir. Katılımcıların, hazırlık aşamasında konu belirlenme ve konu hakkında bilgi edinme çalışmalarında öğretim ilkelerini göz önünde bulundurduğu söylenebilir. Öğretim ilkeleri içerisinde özellikle hayatilik ilkesi üzerinde durulmuş, öğrencilerin hayatta karş̧laştığ ve karşılaşabileceği konuların daha iyi kavrandığı dolayısıyla daha kolay aktarılabildiği belirtilmiştir. Hazırlık aşamasındaki uygulamaların, öğrenciyi aktif kıldığı ve güdülediği söylenebilir. Öğretim teknikleri içerisinde en fazla beyin firtınası hakkında, en az anahtar kelimeleri belirleme hakkında görüş bildirilirken kavram haritası ve çağrışım tekniklerinin kullanıldığı da dile getirilmiştir. Ancak bu teknikler, kullanım kolaylı̆ğ nedeniyle mi yoksa öğrencilerin fikirlerini daha kolay ve hızlı bir şekilde oluşturmalarını sağladığı için mi tercih edilmektedir, 
sorusuna açıklık getirilememiştir. Çünkü hazırlık aşamasında kullanılabilecek başka öğretim teknikleri de vardır ancak hiçbir katılımcı bunlara değinmemiştir. Hazırlık aşamasının öğrencilerin hazırbulunuşluğunu artırdığına yönelik görüşlerin yanında bu aşamanın öğrencilerin yeterli hazırbulunuşluğa sahip olmadıkları nedeniyle uygulanamadığı söylenmiştir. Bu duruma uygulanabilirlik konusunda belirtilen görüşlerde de yer verilmiş, öğrencilerin yapay dil becerilerini öğrenemeden ortaokul sıralarına gelmelerinin, bu yaklaşımın uygulanmasını imkânsızlaştırdığı belirtilmiştir.

K-3. Yazı konusu belirlenirken öğretmen kılavuz kitabında yer alan yönergelerden faydalanıyorum. İşlenen temaya göre de konu seçimini sınırlandırabiliyorum. Serbest bir konu seçimini de nadiren kullanıyorum. Konuyu belirlerken öğrenci fikirlerini ortaya çıkarmak için beyin firtınası tekniğini kullanıyorum. Bazen de bir konu verip araştırma yapmalarını istiyorum. Araştırma sonuçlarını sınıfta paylaşmalarını sağlayacak bu konuyla ilişkili metin oluşturmalarını istiyorum.

K-8. Çalıştığım okul, kırk dört derslikten oluşmakta. Benim Türkçe dersini yürüttüğüm sınıflardan sadece bir tanesinin başarı seviyesi yüksek diyebilirim. Bahsettiğim sınıf, 5. sınıftır. Bu sınıfta yazma çalışması yaparken temel kavramları hep birlikte belirliyoruz. Ben onlara söylemeleri gereken kavramları buluş yöntemi ile söyletiyorum. Çalıştığım okuldaki diğer sınıflardaki öğrenciler, bırakın yazı yazmayı doğru düzgün okumayı hatta Türkçe konuşmayı dahi bilmiyorlar.

Tablo 4. Katılımcıların "planlama aşamasındaki uygulamaları" hakkında görüşleri

\begin{tabular}{lccc}
\hline Planlama & Olumlu & $\begin{array}{c}\text { f } \\
\text { Olumsuz }\end{array}$ & Toplam \\
\hline Öğrenciyi aktif kılma & 10 & - & 10 \\
İçerik kalitesi & 8 & 1 & 9 \\
Metinin bölümleri & 8 & 1 & 9 \\
Aşamalı yazma & 7 & - & 7 \\
Yazmaya yönelik tutum & 4 & 1 & 5 \\
Biçim kalitesi & 3 & - & 3 \\
Bilişsel beceriler & 3 & - & 2 \\
Metinin unsurları & 2 & - & 2 \\
Amaca göre yol belirleme & 2 & - & 2 \\
Uygulanabilirlik & - & 2 & - \\
Biçim kalitesi & 1 & - & 1 \\
\hline
\end{tabular}

Planlama aşamasındaki uygulamalara yönelik en çok öğrenciyi aktif kılma konusunda görüş bildirilmiştir ve görüşlerin hepsi olumludur. Planlama aşaması, öğrencilerin yazma sürecine aktif bir şekilde katılmalarını desteklemektedir denilebilir. Dolayısıyla bu aşamanın; deneyimleyerek öğrenmeyi, yazma sürecine motive olmayı, yazmaya karşı ilgi ve isteği desteklediği söylenebilir. Planlama aşamasında daha çok içerikle ilgili çalışmalar yapıldığından düşünceleri etkili ve düzenli aktarabilme konusunda planlamanın önemli olduğu söylenebilir. $\mathrm{Bu}$ aşamada metnin bölümlerinin ve her bölümde bahsedilecek konuların belirlenmesi, tutarlı ve anlamlı bir metin oluşumunu desteklemektedir. Ancak öğrencilerin metni giriş, gelişme ve sonuç olmak üzere üç paragrafla sınırlandırmaya çalışması, yazma becerisi ve isteği açısından olumsuz bir durumdur. Planlama aşamasında amaca göre yol belirleme, metnin türü ve unsurlarını belirleme gibi çalışmaların, yazma edimine yönelik bilişsel becerilerin gelişimini desteklediği söylenebilir.

K-4. Öncelikle her konuda plan yapmanın insan hayatına olan katkısı konusunda onları bilgilendiriyorum. Bunu yaparken günlük hayatımızdan, günlük işlerimizden örnekler veriyorum. Öğrencilere yazdığımız şeyleri dinletebilmenin en etkili yolunun duygularımızı, düşüncelerimizi güzel ve planlı bir şekilde aktarmak olduğunu uygulayarak anlatıyorum. Bunun için örnek metinler okutuyorum. Bunu yaptıktan sonra da çocuklara yazı yazdırıp planın önemli kavratıyorum.

K-5. Yazma sürecinde çoğunlukla birlikte belirlediğimiz konuyu ve onun çağrıştırdığı alt başlıkları soru-cevap yoluyla belirliyoruz. Ancak öğrenciler en büyük sorunu metnin giriş bölümünde yaşıyorlar. Kompozisyonun başlangıcında çoğunlukla tanım cümleleri yer alıyor. Gelişme bölümünde ise yalnız bir paragraf yazılıyor, konuyu sınırlı bir açıdan anlatan cümleler yer alıyor. Sonuç bölümünde ise öğrenciler vermeyi planladıkları ana fikri, iki ya da üç cümle ile yazıyorlar. 
Tablo 5. Katılımcıların “düșünce belirginleștirme ve geliştirme uygulamaları” hakkında görüşleri

\begin{tabular}{lccc}
\hline Geliştirme & f & Toplam \\
\hline İçerik kalitesi & Olumlu & Olumsuz & 11 \\
Öğrenciyi aktif kılma & 7 & 4 & 11 \\
Yazmaya yönelik tutum & 11 & - & 9 \\
Öğretim ilkeleri & 9 & - & 5 \\
Hazırbulunuşluk & 5 & - & 4 \\
Konuyla ilgili bilgilendirme & 2 & 2 & 4 \\
Bilişsel beceriler & 4 & - & 3 \\
Çoklu ölçme ve değerlendirme & 3 & - & 3 \\
Düşünceleri aktarabilme & 3 & - & 2 \\
Uygulanabilirlik & 2 & - & 2 \\
Yazma beceri gelişimi & - & 2 & 2 \\
Zaman & 2 & - & 1 \\
Biçim kalitesi & 1 & 1 & 2 \\
\hline
\end{tabular}

Katılımcı görüşleri en fazla içerik (olumsuz) ve öğrenciyi aktif kılma (olumlu) hakkında yoğunlaşmaktadır. Geliştirme aşamasının içerik kalitesini artırdığı belirtilirken, öğrencilerin uygulama sırasında ön bilgilerinin eksik olması, üst düzey becerilerini ve düşünceyi geliştirme yollarını kullanamamaları sebebiyle içeriğin geliştirilemediği belirtilmiştir. Düşüncenin belirginleştirilmesi ve geliştirilmesi, yazmaya yönelik tutumu olumlu yönde etkileyebilmektedir. Geliştirme aşamasının; öğretim ilkelerinin, bilişsel becerilerin, çoklu ölçme ve değerlendirme yönteminin kullanımını gerektirdiği ve yazma becerisini desteklediği söylenebilir. Buna karşın geliştirme aşamasında öğrenciler hazırlık ve planlama aşamamalarından geçerek hazırbulunuşluklarını artırmaktadır. Ancak geliştirmeden önceki aşamalarını eksik bırakan öğrenci, bu aşamaya gerekli bilgi ve birikime sahip olmadan geçmektedir. Bu durumun, yazma gelişimini olumsuz etkilediği gibi zaman ve motivasyon kaybına neden olduğu söylenebilir.

K-2. Oluşturdukları maddeleri gözden geçirmelerini ve konuyla ilgili maddeleri belirlemelerini, daha az ilgisi olan veya hiç ilgisi olmayan maddeleri elemelerini istiyorum. Konuyu geliştirirken öğrencilerin aklına çok fazla bir şey gelmiyorsa örnek olay ya da gözlemlerimi aktarıyorum. Bunun yanında onlardan da konuyla ilgili gözlem yapmalarını veya konuyla ilgili varsa bir eksiklik tekrar ayrıntılı araştırma yapmalarını istiyorum.

K-8. Öğrencilerime günlük hayattan örnekler vererek yardımcı olmaya çalışıyorum. Günlük yaşamda sıklıkla kullandıkları, hayatlarında yer etmiş olan kişi ve durumları; belirleyeceğim düşüncenin merkezine yerleştiriyorum. Yakından uzağa, bilinenden bilinmeyene ilkesini kullanarak öğretimde verimlilik elde etmeye çalış1yorum.

Tablo 6. Katılımcıların "düzeltme aşamasındaki uygulamaları" hakkında görüşleri

\begin{tabular}{lccc}
\hline Düzeltme & Olumlu & $\begin{array}{c}\text { f } \\
\text { Olumsuz }\end{array}$ & Toplam \\
\hline Çoklu ölçme ve değerlendirme & 18 & - & 18 \\
Öğrenciyi aktif kılma & 10 & - & 10 \\
İçerik kalitesi & 8 & 1 & 9 \\
Hataları düzeltme ve öğrenme & 8 & - & 8 \\
Bilişsel beceriler & 7 & - & 7 \\
Hataları fark etme & 7 & - & 7 \\
Biçim kalitesi & 5 & 1 & 6 \\
Yazma beceri gelişimi & 6 & - & 6 \\
Yazmaya yönelik tutum & 4 & 1 & 5 \\
Hazırbulunuşluk & - & 3 & 3 \\
Saygi unsurları & 1 & 1 & 2 \\
Model oluşturma & 1 & - & 1 \\
Uygulanabilirlik & - & 1 & 1 \\
\hline
\end{tabular}

STYY'nin düzeltme aşamasında yapılan çalışmalara dair katılımcılar, hepsi olumlu olmak üzere en çok görüşü çoklu ölçme ve değerlendirme konusunda dile getirmişlerdir. Çoklu ölçme ve değerlendirme yaklaşımı; içerisinde 476 
öz, akran ve öğretmen değerlendirmelerini barındırmakta, süreç odaklı bir değerlendirmeyi önermektedir. Bu durum düzeltme aşamasında öğrencilerin öğretmenlerle birlikte ölçme ve değerlendirme sürecine katılmasına, öğrenci başarısının her açıdan değerlendirilmesine ve öğrencilerin eksiklerinin ortaya konulmasına olanak sağlamaktadır. Düzeltme aşamasındaki uygulamalar öğrencinin yazma sürecine aktif katılımını ve yazmaya yönelik olumlu tutum geliştirmesini sağlayabilmektedir. Geliştirme aşamasının biçim ve içerik kalitesini artırdığına dair görüşler yoğunluktadır. Özellikle biçim kalitesine yönelik; hazırlık, planlama ve geliştirme aşamalarında çok az görüş bildirilmişken bu aşamada görüş frekansının yükselmesi yaklaşımın doğru uygulandığının yansımasıdır. Çünkü yazılan metnin sunuma uygun hale getirilmesi amacıyla biçim kalitesine yönelik çalışmalar, yayımlamadan önceki aşama olan düzeltme aşamasında uygulanmaktadır. Ancak gereğinden fazla biçimsel kurallara odaklanılması, yazmaya yönelik tutumu olumsuz etkileyebilmektedir. Öğrencilerin yazma sürecinde etkileşim içerisinde olmasını sağlayan akran değerlendirme, başkalarının görüşlerine saygılı olmayı öğretmesi bakımından önemlidir. Ancak değerlendirmede saygı unsurlarının çiğnenmesi olumsuz bir durum oluşturabilmektedir. Düzeltme aşamasında yapılan uygulamaların, öğrencilerin hatalarını fark etmesini ve düzeltmesini sağladığı, bilişsel gelişimlerini olumlu etkilediği söylenebilir. Böylece öğrencilerin eksiklerini gidererek etkili ve kalıcı öğrenmeleri sağlanmakta, yazma beceri gelişimleri desteklenmektedir. Hazırbulunuşluk konusunda, öğrencilerin yazmayı öğrenmemiş olmalarından ve önceki aşamaları gerektiği şekilde uygulayamamış olmasından kaynaklanan sorunlar yaşandığı söylenebilir.

K-3. Anlatım olarak öncelikle kendini değerlendirmesini istiyorum. Bazen hazır ön değerlendirme formlarını kullanıyorum. Böylece öğrenci de farkındalık oluşmasını sağlıyorum. Hatanın öğrenilmesinden çok kendi kendine fark edilmesi hatayı düzeltme de ve bir daha yapmama konusunda daha faydalı. Yazdığı konuyu birkaç kez sesli okutarak anlatım olarak kulağa hoş gelmeyen ifadeleri arkadaşlarının belirlemesini istiyorum. Bu diğer ögrencilerin benzer hatalar yapmasını azaltmaktadır.

K-12. Yazıya planla başladığımız için önce planı hazırlıyorlar. Ben planlarını tek tek incelerim. Genelde konu ve ana fikir karışır ya da birbirinden bağımsız olabilir. Yaptığı yanlıştan hareketle konuyu yeniden bireysel anlatırım. Herkesin planının doğru olduğuna kanaat getirince hep beraber gelişmeye geçiyoruz. Bu şekilde bölüm bölüm düzelterek gidiyoruz. Hatalarını daha net fark ediyorlar ve bir dahaki bölümde daha az hata yapiyorlar.

Tablo 7. Katılımcıların “öğrencilerin yayımlama aşamasındaki davranışları” hakkında görüşleri

\begin{tabular}{lccc}
\hline Yayımlama & Olumlu & Olumsuz & Toplam \\
\hline Paylaşma isteği & 10 & 4 & 14 \\
Özgüven & 7 & 6 & 13 \\
Yazmaya yönelik tutum & 8 & 4 & 12 \\
Dönüt & 8 & - & 8 \\
Bilişsel beceriler & 3 & - & 3 \\
Temel dil becerileri & 3 & - & 3 \\
Yazma beceri gelişimi & 3 & - & 3 \\
Uygulanabilirlik & - & 2 & 2 \\
\hline
\end{tabular}

Katılımcılar, öğrencilerin yayımlama aşamasındaki davranışlarına ve tepkilerine yönelik en çok paylaşma isteği hakkında görüş belirtmişlerdir. Bu konudaki katılımcı görüşlerinin çoğu, yayımlama aşamasının öğrencilerin paylaşma isteğini desteklediği ve öğrencilerin yazdıklarını paylaşmak istediği yönündedir. Ancak bazı öğrencilerin çeşitli nedenlerle yazdıklarını kimsenin görmesini istemeyişleri, bu aşama için olumsuz bir durum oluşturmaktadır. Yayımlama aşamasında öğrencilerin en çok özgüven problemi yaşadıkları ve bu durumun STYY'nin uygulanmasını zorlaştırdığı söylenebilir. Buna karşıı özgüven konusunda belirtilen olumlu görüşler ise bu aşamanın, öğrencilerin özgüvenlerini olumlu etkilediğinin yansımasıdır. Bulgulardan hareketle yayımlama aşamasının öğrencilerin yazma isteğini ve eğilimini artırdığı, yazmaya yönelik olumlu tutum geliştirmelerini desteklediği söylenebilir. Öğrencilerin yazdıklarının yayımlanması sonucunda çevrelerinden olumlu dönüt bekledikleri, aldıkları dönütler sonucunda yeniden yazma ve yayımlama isteği gösterdikleri belirtilmiştir. Yayımlama aşamasının, öğrencilerin bilişsel, yazma ve temel dil becerilerine olumlu yansımalarının olduğu söylenebilir. Ancak gerek öğrencilerin tepkileri gerekse yetersiz yazma becerilerine sahip olmaları nedeniyle bu aşamanın uygulanabilirliğinde problemler yaşandığı söylenebilir. 
K-8. Yayımlama aşamasını sınıf panosunu kullanarak gerçekleştiriyorum. Yazdıkları metinlerin sınıf panosuna asılacağını söylediğimde kimse razı olmuyor. Hepsi itiraz ediyor. Bu aşamada çok zorlanıyorum. Sınıfta arkadaşlarına rahatlıkla okudukları metinlerini neden panoya asmak istemediklerini anlamlandıramıyorum. Kendilerine ait bir materyalin panoda, herkesin görebileceği, tekrar tekrar inceleyebileceği bir alanda olması öğrencilerimi huzursuz ediyor.

K-13. Bir öğrencinin ortaya çıkardığı bir ürünün olması kendisini çok mutlu etmektedir. Bu aynı zamanda takdir edilme, kabullenilme ve kendini geliştirme için çok güzel teşvik olmaktadır. Genellikle sonraki aşamalarda takdir edilen yazıları yayımlanan öğrencilerin yazma becerileri geliştirmek için daha gayretli olduklarını gördüm. Diğer arkadaşları için de iyi bir örnek teşkil etmektedir.

Tablo 8. Katılımcıların "STYY'nin uygulanmasında yaşanılan zorluklar" hakkında görüşleri

\begin{tabular}{lccc}
\hline Uygulama & Olumlu & Olumsuz & Toplam \\
\hline Zaman & - & 17 & 17 \\
Yazma aşamaları & - & 11 & 11 \\
Hazırbulunuşluk & - & 10 & 10 \\
Uygulanabilirlik & - & 8 & 8 \\
İçrik kalitesi & - & 5 & 5 \\
Yazmaya yönelik tutum & - & 5 & 5 \\
Yazma beceri gelişimi & 1 & 3 & 4 \\
Yazma süreci & - & 4 & 4 \\
Biçim kalitesi & - & 1 & 1 \\
Dönüt & - & 1 & 1 \\
Hayal dünyası & - & 1 & 1 \\
Yazma becerisinin zorluğu & - & 1 & 1 \\
\hline
\end{tabular}

STYY'nin uygulanmasında yaşanılan zorluklara yönelik görüşlerin zaman konusunda yoğunlaştı̆̆ı ve en çok olumsuz görüşün de bu konuda belirtildiği görülmektedir. Bu yaklaşımın uzun süren yazma uygulamaları içermesi nedeniyle daha fazla ders saatine ihtiyaç duyulduğu söylenebilir. Katılımcılar genellikle STYY'nin fazla zaman aldığı için öğrencilerin yazma sürecinden koptuklarını; uzun bir süreç gerektirdiğinden bu yaklaşımda yapılan çalışmaların sayıca yetersiz kaldığını belirtmişlerdir. Yazma aşamaları ile ilgili görüşler, uygulanabilirliği olumsuz etkilediği yönündedir. Katılımcılar, öğrencilerin yeterli hazırbulunuşluğa sahip olmamaları, okuma ve yazma öğrenimini tamamlayamamış olmaları ve hazırlık çalışmalarıyla hazırbulunuşluklarını sağlayamamaları nedeniyle uygulanabilirlik konusunda ciddi problem yaşadıklarını belirtmişlerdir. Burada karşımıza en büyük problem olarak ilkokul döneminde öğrenilmesi gereken becerilerin kazandırılamamış olması çıkmaktadır. Araştırmanın geneli göz önünde bulundurulduğunda, katılımcıların her soruda uygulanabilirlik konusunda görüş bildirmesi ve bu görüşlerin olumsuz olması dikkat çekmektedir. Bu durum katılımcıların STYY'yi uygulama konusunda ciddi zorluklar yaşadığının ve yeterince uygulamadığının yansımasıdır. Bu konuda tek olumlu görüş yazma beceri gelişimi hakkında verilmiştir. Katılımcılar, STYY'nin uygulanmasının yazma becerilerini geliştirdiğini düşünseler de bu yaklaşımın öğrenilenleri beceri haline getirme noktasında eksik kaldığını belirtmişlerdir. Öğrencilerin yazmaya yönelik olumsuz tutumları, yazma sürecindeki bazı uygulamaların ve içerik kalitesini sağlamanın zorluğu, STYY'nin uygulanabilirliğini olumsuz etkilemektedir.

K-1. Öğrencinin yazma çalışmasıyla bireysel olarak ilgilenmek fazla zaman harcanmasına neden olmaktadır. Öğretmenlerin tüm öğrencilerin yazdıklarını incelemesi, bazı paragrafla ilgili onlarla konuşması, burada ne anlatmak istediğini sorması zaman alıcı bir durumdur. Ayrıca yazılacak konunun ve kavramlarının belirlenmesinde sınıf ortamında öğrencilerin görüşleri alındığı için -hepsi olmasa da bazı öğrencilerde- konuya aşırı ilgi gösterme ve hep kendi söylediklerinin tahtaya yazılması isteğiyle karşılaşılmaktadır.

K-7. Bu model sabır gerektiren ve emek isteyen bir modeldir. Pratikteki süreç ile uygulamadaki süreç farklı olabiliyor. Bu da her öğrencinin birbirinden bağımsız olarak ilerleyebileceğini kanıtlıyor. Yani hâlâ okuma yazmayı öğrenemeyen yetişkin öğrencilerin olduğunu düşünürsek bu modelde de istenilen sonuca henüz ulaşılmadığını söyleyebiliriz. Benim hâlâ okuma yazma bilmeyen öğrencilerim var ve bu hem onlar için hem de okuma yazma bilenler için sabır gerektiren bir durum. 
Tablo 9. Katılımcıların “STYY’nin edebiyat ve yazmaya yönelik tutuma etkisi” hakkında görüşleri

\begin{tabular}{lccc}
\hline Yazma tutumu & Olumlu & f & Olumsuz \\
\hline Yazmaya yönelik tutum & 27 & 1 & 28 \\
Yazma beceri gelişimi & 13 & - & 13 \\
Öz güven & 6 & - & 6 \\
Uygulanabilirlik & 1 & 4 & 5 \\
Çoklu ölçme ve değerlendirme & 5 & - & 5 \\
Aşamalı yazma & 2 & - & 2 \\
Öğrenciyi aktif kılma & 2 & - & 2 \\
Temel dil becerileri & 2 & - & 2 \\
\hline
\end{tabular}

Katılımcı görüşlerine göre, STYY öğrencilerin yazmaya yönelik tutumlarını olumlu yönde etkilemektedir. Buradan hareketle STYY'nin özgüven ve yazma beceri gelişimini desteklediği; bu durumun, öğrencilerin yazmaya yönelik tutumlarına olumlu yansıdığı söylenebilir. STYY'nin, öğrencilerin aşamalı bir şekilde yazmalarını sağladığı, çoklu ölçme ve değerlendirme yaklaşımıyla sürece aktif katılımlarını desteklediği söylenebilir. Dolayısıyla tüm bu olumlu özellikleri, yazmaya yönelik yaklaşıma olumlu yansımaktadır. Ek olarak, temel dil becerilerinin gelişim noktasında birbirlerini etkilemesi nedeniyle bu yaklaşımın sadece yazma becerisinin gelişimini sağlamakla sınırlı kalmadığı görülmektedir. Sadece uygulanabilirlik noktasında olumsuz görüşler bildirilmiştir. Bu durum STYY uygulanırken karşılaşılan güçlüklerin, öğrencilerin yazmaya yönelik tutum tutumlarına olumsuz yansıdığının işareti olarak gösterilebilir.

K-6. Yazmaya daha bilinçli olarak başladıklarını ve yazdıkları türe ait özellikleri yansıtmakta, ortaya koymaya çalıştıkları düşüncelerini belirginleştirmeye çalıştıklarını gözlüyorum. Öğrenciler ortaya metin koyduklarında seviniyorlar. Paylaşma aşamasında beğenilen metinler olunca öğrenci daha bir seviniyor. Dikkatimi çeken bir nokta da yazma çalışması yapacağız dediğimde öğrencilerin çoğunda olumsuz bir tutum görmüyorum.

K-10. Yazma fobisi öğrencide daima var. Aslolan bu fobiyi nasıl yok etmek olmalı. Yazı yazarken yazının harf güzelliğinden ziyade yazının içerikle süslenebileceğini de anlamaktalar. Yazılarını daha iyi yazabilmek için atasözleri, deyimler, özdeyişler gibi söz gruplarıyla içeriği desteklerken bunları kullanmaktan da keyif alıyorlar. Her yazının sonunda kendilerini adeta ünlü bir yazar olarak görüyorlar.

Tablo 10. Katılımcıların "süreç temelli ölçme ve değerlendirme uygulamaları" hakkında görüşleri

\begin{tabular}{lccc}
\hline Ölçme ve değerlendirme & Olumlu & Olumsuz & Toplam \\
\hline Yazma beceri gelişimi & 13 & - & 13 \\
Analitik değerlendirme & 9 & - & 9 \\
Öğrenciyi aktif kılma & 6 & - & 6 \\
Süreç temelli değerlendirme & 6 & - & 6 \\
Yazmaya yönelik tutum & 5 & - & 5 \\
Çoklu ölçme ve değerlendirme & 3 & - & 3 \\
Kişisel gelişim & 3 & - & 3 \\
Bilişsel beceriler & 2 & - & 2 \\
Uygulanabilirlik & - & 2 & 2 \\
\hline
\end{tabular}

STYY'da kullanılan ölçme ve değerlendirmeler öğrencinin sürece aktif katılımını sağlayarak bütünsel gelişimini desteklemektedir. Bu yaklaşımın, çoklu ölçme ve değerlendirme, analitik değerlendirme ve süreç temelli değerlendirme biçimlerini içerdiği görülmektedir. Analitik değerlendirme, biçim, içerik, dil kullanımı gibi alt dallara ayrıştırarak her açıdan değerlendirmeyi sağlarken; çoklu ölçme ve değerlendirme, öğretmen ve öğrencilerin değerlendirme sürecine birlikte katılımını sağlamaktadır. Süreç temelli değerlendirme bu iki değerlendirme türünü desteklemekte ve daha çok öğrencilerin yazma sürecindeki faaliyetlerini değerlendirmektedir. Tüm bu değerlendirme yapılarını içermesi nedeniyle STYY, öğrencilerin yazma sürecine aktif katılmalarını sağlamakta ve yazmaya yönelik tutumlarını olumlu yönde destekleyebilmektedir. STYY'nin içerdiği ölçme ve değerlendirmelerin uygulanabilirliğinin öğretmenler açısından zor olduğu söylenebilir. Bu durum, öğretmenlerin tüm öğrencileri kontrol ederek dönüt vermesi gerekliliğinden ve akran değerlendirme noktasında saygı unsurlarının aşılmasından kaynaklanabilir. 
K-7. Akran değerlendirmeye sıkça başvuruyorum. Öğretmenlerin gözünden kaçan şeyler öğrencilerin gözünden kaçmayabiliyor. Ve öğrenciler sınıf ortamında bir birey olduğunu hissedince kendi düşüncelerine ve karşısındakinin düşüncelerine saygı duymayı öğreniyor. Bu şekilde fikirlerini dile getirmekten çekinmeyip sınıf ortamında varlığını ortaya koyuyor.

K-13. Yazılı anlatımda ölçme, istenilen standardın yani ilerlemenin gelişip gelişmediğine yöneliktir. Türkçenin temel kurallarından istenilen verilmiş mi, tertip ve düzen sağlanmış mı, yazım ve imlâ kurallarına uyulmuş mu, istenilen büyüklükte mi, uygun başlık atılmış $\mathrm{m} 1$, giriş genel ifadelerle başlamış mı, gelişme bölümü olay örüntüleri kullanılarak geliştirilmiş mi, düşünceyi geliştirme yolları uygun şekilde kullanılmış mı gibi ölçme soruları oluşturulur ve buna göre incelenip öğrenciyle beraber değerlendirme yapıyorum.

Tablo 11. Katılımcıların STYY ile ilgili görüş ve önerileri.

\begin{tabular}{lccc}
\hline Görüş ve öneriler & Olumlu & Olumsuz & Toplam \\
\hline Uygulanabilirlik & - & 10 & 10 \\
Yazma beceri gelişimi & 9 & - & 9 \\
Hazırbulunuşluk & - & 8 & 8 \\
Yazma süreci & 4 & 1 & 5 \\
Yazmaya yönelik tutum & 2 & 3 & 5 \\
Öğrenciyi aktif kılma & 3 & - & 3 \\
Bilişsel beceriler & 2 & - & 2 \\
Çoklu ölçme ve değerlendirme & - & 2 & 2 \\
Bütünsel gelişim & 1 & - & 1 \\
Özgüven & - & 1 & 1 \\
\hline
\end{tabular}

Katılımcıların STYY hakkında yöneltilen sorular dışında kalan belirtmek istedikleri düşünceler ele alındığında en çok görüşün uygulanabilirlik noktasında yoğunlaştığı görülmektedir. Bu konuda belirtilen düşüncelerin hepsinin olumsuz olması katılımcıların STYY'yi tam olarak uygulayamamalarının yansımasıdır. Katılımcılar, uygulama noktasında yaşadıkları zorlukları tekrar dile getirme ihtiyacı duymuşlardır. STYY'nin uygulanmasının; çevre ve sınıf ortamı, öğrenci seviyeleri, ders saati ve zaman konularında yaşanan problemlerden olumsuz şekilde etkilendiği ifade edilmiştir. Tüm bu etmenlerin neden olduğu sıkıntıların yanında öğretmenlerin yetersizlikleri de uygulanabilirliğe olumsuz yansıyabilmektedir. Buna karşın eldeki bulgular STYY'nin öğrencilerin yazma beceri gelişimlerini, bilişsel ve bütünsel gelişimlerini, olumlu yönde desteklediğini göstermektedir. Ayrıca bu yaklaşımın öğrenciyi aktif kıldığı ve yazma sürecini olumlu etkilediği yorumu yapılabilir. Öğrencilerin hazırbulunuşluk açısından yetersiz olması; hazırlık aşamasında yeterli bilgi edinerek, eksiklerini giderememelerinden kaynaklanabilir. Öğrencilerin genel olarak yazmaya karşı özgüvensiz, önyargılı ve kaygılı olmalarından kaynaklanan olumsuz tutumları, uygulama konusundaki hata ve eksiklikler nedeniyle yayımlama ve değerlendirme süreçlerinde artabilmektedir. Kendi yazdıklarının, akranlarının yazdıklarıyla karşılaştırılan ya da olumsuz eleştiriler alan çocukların özgüvenleri olumsuz etkilenebilmektedir. Tüm bu olumlu ve olumsuz değerlendirmeler birlikte ele alındığında STYY'nin doğru ve etkili uygulandığında bilişsel, duyuşsal, psiko-motor ve kişilik gelişimlerinin yanında yazma becerilerini ve yazmaya yönelik tutumlarını olumlu yönde desteklediği ifade edilebilir. Ancak uygulama konusunda yaşanılan zorluklar, eksiklikler ve yetersizlikler nedeniyle öğrencilerin yazma tutumlarını, yazma sürecini ve öz güvenlerini olumsuz yönde etkilediği de söylenebilir.

K-1. Sadece ürün odaklı yazma çalışmalarına göre süreç odaklı yazma çalışmalarının öğrenci için daha iyi olduğunu düşünüyorum. Bu yaklaşımda öğrenci, yazmanın adım adım yapıldığını ve her aşamada ne kadar dikkatli olması gerektiğini öğrenmektir. Klasik yazma yönteminde işini içine kapanık olarak yapan öğrenci süreç temelli yazma yaklaşımında aynı zamanda sosyalleşmektedir.

K-11. Bu modeli derste uygulayamıyorum. Daha da vahim olanı yapılandırmacı sistemin birçok verisinden faydalanamıyorum. Öğrencilerimin ön bilgileri çok yetersiz. Ailelerinin ekonomik durumları oldukça kötü. Aileleri çocuklarla hiç ilgilenmiyor. Muhtemelen ilkokulda da öğretmenler yeteri kadar ilgi ve desteği gösteremedikleri için bu süreçte büyük sıkıntılar yaşıyorum. Elimden gelenin en iyisini yapmaya çalışıyorum.

\section{Tartışma ve Sonuç}

Katılımcıların STYY'nin yazma becerilerine katkısı konusundaki görüşleri; öğrencilerin yazmaya yönelik tutumlarını, yazma becerilerini, bilişsel ve kişisel gelişimlerini, temel dil becerilerini olumlu etkilediği üzerinde 
yoğunlaşmaktadır. Buna karşın zaman ve uygulanabilirlik açısından sorun yaşandığı belirtilmiştir. STYY, yazma işlemini bir dizi aşamalara dönüştürmesi, bilgi ve becerilerin doğru bir şekilde uygulanarak ilerlenmesi açısından öğretmen ve öğrencilere kolaylık sağlamaktadır (Badger \& White, 2000). Deneysel desendeki bir araştırmada STYY'nin öğrencilerin yazmaya karşı tutumlarını, yazma alışkanlıklarını ve becerilerini olumlu yönde etkilediği tespit edilmiştir (Ho, 2006). Bu yaklaşımın, kompozisyon yazma becerilerine katkı sağlamanın yanında, öğrencilerin aktif katılımını sağladığı, özgüvenlerini ve yazma isteklerini olumlu yönde etkilediği tespit edilmiştir (Yılmaz \& Aklar, 2015). Ürün temelli yaklaşımla kıyaslandığında STYY'nin öğrencilerin yazma becerilerini daha fazla geliştirdiği saptanmıştır (Zhou, 2015). Yapılan bir diğer deneysel araştırmada bu yaklaşımın öğrencilerin yaratıcı yazma becerilerinin gelişimine de katkı sağladığı tespit edilmiştir (Sever, 2013). Yapılan araştırmaların çoğu, STYY'nin öğrencilerin yazılı anlatım becerilerini olumlu etkilediğini göstermektedir (Balc1, 2017; Karatosun, 2014; Sever, 2013; Şentürk, 2009). Araştırmanın bulguları bu açıdan desteklenmektedir.

STYY’nin hazırlık aşamasına yönelik görüşlerin analiz edilmesi sonucunda bu aşamadaki uygulamaların, öğrencinin aktif katılımını, güdülenmesini ve yazma isteğini desteklediği söylenebilir. Bunun yanında katılımcılar; öğrencilerin, bu aşamayı yeterli değerlendiremediklerinde sonraki aşamalar için hazırbulunuşluklarını sağlayamadıklarını ve bu aşamanın fazla zaman aldığını vurgulamışlardır. Ayrıca ilkokulda kazanılması gereken becerilerin edinilmemiş olması da bu durumun nedenlerindendir. Bireyin yazma kazanımının bir süreç olarak görülmesi ve uygulanması gerektiği, bu sürecin ilk okuma yazma öğretiminden başlanarak adım adım gerçekleştirilmesi ve gelişim sağlandıkça yeni kazanımlar öğretilmesinin doğru olacağı saptanmıştır (Okari, 2016). Yazma sürecinde uygulanan faaliyetlerin çoğu hazırlık amaçlıdır ve öğrencilerin yazma işlemine hazırlanmalarının ölçme ve değerlendirme uygulamalarını desteklediği belirtilmiş̧ir (Storch, 2005). Planlı yazma ve değerlendirme modelinin, yazma sürecinin \%70'ini hazırlık aşamasına ayırarak öğrencilere daha fazla plan yapma ve fikir üretme konularında firsat sağladığı tespit edilmiştir (Yılmaz, 2012). Buradan hareketle denilebilir ki; hazırlık aşaması STYY'nin uygulanabilmesi adına hayati öneme sahip olan, doğru ve tam uygulanması gereken bir aşamadır. Öğrencilere hazırlık aşamasının önemi kavratılmalı ve bu aşamayı tam olarak uygulamaları sağlanmalıdır. Bu konuda öğrencilerin ilgisini, isteğini diri tutacak, onları güdüleyerek aktif bir şekilde sürece katılımlarını sağlayacak etkinlikler tasarlanmalı ve bu etkinlikler eğitsel ortamlara, sınıflara taşınmalıdır.

Planlama aşamasındaki uygulamaların genel olarak, metnin içerik ve biçim kalitesine, amaca uygun hareket edilmesine, metnin unsurlarının ve bölümlerinin belirlenmesine katkı sağladığı söylenebilir. Buna ek olarak bu aşamanın öğrencilerin aktif olmasına, olumlu yazma tutumlarına, aşamalı yazma ve bilişsel becerilerine katkı sağladığı yönünde görüşler tespit edilmiştir. Ancak uygulanabilirlik konusunda yine sorunlar yaşandığı belirtilmektedir. $\mathrm{Bu}$ aşamada yazma taslağı oluşturularak verilmek istenen mesajlar hedef kitleye daha etkili bir şekilde aktarılabilir (Reimer, 2001). Bu konuda yapılan bir araştırmada yazma alışkanlığı ve başarısı düşük olan kişilerin iyi bir plan oluşturmadıkları, planlama becerilerinin eksik olduğu tespit edilmiştir (Jensen \& DiTiberio, 1984). Sistematik planlama sürecine dayalı STYY, öğrencinin bilişsel farkındalığını ve metnin içerik kalitesini desteklemekte; öğretmen-öğrenci ilişkisini ve öğrenme sürecini düzenlemektedir (Johari, 2018; Duman, 2007). Araştırmada ulaşılan sonuçlar alanda yapılan çalışmaların sonuçlarını destekler niteliktedir. Bu açıdan planlama becerisinin yazma becerilerini pek çok yönden desteklediği söylenebilir.

Geliştirme aşamasının; öğrencinin aktif katılımını, yazmaya yönelik olumlu tutumunu, bilişsel ve yazma becerilerinin gelişimini, düşüncelerini aktarabilmesini desteklediği yönünde görüşler tespit edilmiştir. Ancak görüşler doğrultusunda, biçim kalitesi ve uygulanabilirlik konusunda olumsuzluklar yaşandığı söylenebilir. Yapılan araştırmalar elde edilen sonuçların olumlu yönünü desteklemektedir. STYY; yazılanları yeniden okuma, sorgulama, değerlendirme, gözden geçirme işlemleriyle yazma becerilerinin gelişimini desteklemektedir (Zare-ee \& Mahdavi, 2014). Bu aşamada öğretmen ve akran değerlendirmelerinin kullanımı, metin kalitesini ve yazma becerilerini olumlu yönde etkilemektedir (Tuan, 2011). Geliştirme aşaması; öğrencilerin birbirleriyle etkileşim içerisinde olmasını sağlarken iş birliğini ve iletişimi mümkün kılmaktadır (Storch, 2005). Yazma taslağı oluşturma, düşünceleri düzenleme ve gözden geçirme gibi çalışmalar bilişsel farkındalığı artırmakta ve yazma becerilerini desteklemektedir (Karatay, 2011). Bu doğrultuda denilebilir ki süreç temelli yaklaşımı, yazma becerilerini ve bilişsel becerileri desteklemektedir. Geliştirme aşamasında, daha çok fikirlerin doğru ve etkili yazılabilmesi üzerinde durulur (Seow, 2002). Ancak bu aşamada yazım, noktalama ve dil bilgisi kurallarını öğrenciye dayatmak çeşitli sorunlara neden olacaktır. Dolayısıyla biçim kalitesine yönelik belirlenen olumsuz görüşlerin temelinde, STYY'nin yanlış uygulanılması olduğu söylenebilir. Alanda yapılmış araştırmalarda istatiksel olarak benzer bir sonuç elde edilememesinin nedeni de buradan kaynaklanıyor olabilir. 
Düzeltme aşaması; çoklu ölçme ve değerlendirme yaklaşımının kullanımına olanak sağlaması bakımından öğrencilerin yazma becerisine, yazmaya yönelik tutumlarına, hatalarını fark etmelerine ve düzeltmelerine, metnin içerik ve biçim kalitesine katkı sağlamaktadır. Ancak akran değerlendirme sürecinde bazen saygı unsurlarının ihlal edilebildiği belirtilmiş̧tir, dolayısıyla öğretmenlerin bu konuda dikkatli davranması gerekmektedir. Ayrıca öğrencilerin önceki aşamaları yeterince değerlendirememiş olmaları ve ilkokulda edinilmesi gereken becerileri öğrenememiş olmalarından kaynaklanan sorunların olduğu da dile getirilmiştir. Bu konuda gerçekleştirilen deneysel araştırmada üslup, içerik, dil bilgisi, yazım ve noktalama konularında STYY'e yönelik olumlu yönde anlamlı fark bulunmuştur (Kallestinova, 2017). Süreç temelli yazma uygulamaları yapan öğrencilerin; yazım, üslup, cümle akıcıllğı, kelime seçimi ve sunum özellikleri bakımından ilerleme kaydettikleri tespit edilmiştir (Görgüç, 2016). Düzeltme aşamasının gerektirdiği ölçme ve değerlendirme uygulamalarının, yazma becerisine, biçim ve içerik açısından kaliteli metin üretimine katkı sağladığı söylenebilir.

Yayımlama aşamasına yönelik görüşlerin analizi sonucunda, bu aşamanın öğrencilerin paylaşma isteğini, öz güvenlerini, yazmaya yönelik tutumlarını, bilişsel, temel dil ve yazma becerilerini olumlu yönde etkilediği söylenebilir. Ancak öğrencilerin yazma kaygıları, önyargıları, öz güven eksiklikleri ve uygulanabilirlik konusunda yaşadıkları sorunlar bu aşama için olumsuzluk teşkil etmektedir. Yayımlama aşaması; öğrencilerin düzeltme aşamasına odaklanmaları sağladığından öğrencileri metnin içerik ve biçim kalitesini oluşturma, okuyucunun isteklerini karşılama konularında titiz davranmaya yöneltir (Kallestinova, 2017). Yayımlama aşamasının, bireyin yazma tutum ve öz güvenini olumlu yönde etkilediği tespit edilmiştir (Selanikli, 2015).

STYY’nin uygulanabilirliğine yönelik katılımcı görüşlerinin analizi sonucunda; yaklaşımın aşamalarının, zaman yetersizliğinin, hazırbulunuşluk ve hayal dünyası eksikliğinin, biçim ve içerik kalitesine yoğunlaşmanın, konuların uygulanabilirliğini olumsuz etkilediği iddia edilmiştir. Öğretmenlerin yazma öğretimine yönelik en çok zaman yetersizliği, sınıf mevcudunun fazlalığı, eğitim eksikliği konularında sorun yaşandığı tespit edilmiştir (Krendl \& Dodd, 1987). STYY'nin uygulanmasında karşılaşılan zaman sorununu ortadan kaldırmak adına seçmeli yazma dersleri eklenebilir ya da Türkçe ders saatleri artırılabilir. Öğretmenlerin tüm öğrencilerle yeterince ilgilenebilmesi ve dönüt verebilmesi için sınıf mevcutları azaltılmalıdır. Belirtilen tüm olumsuzluklar sadece yaklaşımın uygulanabilirliğine değil, doğal olarak öğrencilerin yazma becerilerine de olumsuz şekilde yansımaktadır. STYY'nin tam ve doğru uygulanması konusunda öğretmenler titiz davranmalıdır. Özellikle yazım, noktalama ve dil bilgisi kuralları öğrencilere dayatılmamalı, öğrencilerin yazma tutumu önemsenmeli, iletişimsel yeti merkeze alınmalıdır. Söz varlığı ve gramer bilgisi eksiklikleri nedeniyle öğrencilerin, öğretmenin dönütlerini uygulamada ve kendilerini doğru ifade etme konusunda sorunlar yaşadıkları bilinmektedir (Zhou, 2015). Yaklaşımın uygulanmasında bu durumun olumsuz yansımaları olduğu söylenebilir. Araştırmanın bütün alt problemlerinde, yaklaşımın uygulanmasında çeşitli sorunlar yaşandığına yönelik görüşler tespit edilmiştir.

Öğrencilerin edebiyata ve yazmaya yönelik tutumlarına STYY'nin olumlu etki ettiğine yönelik görüşler mevcuttur. Bu konudaki katılımcı görüşleri bu modelin, öğrencilerin derse aktif katılımlarını, öz güvenlerini, temel dil ve yazma becerilerini artırdığı yönündedir. Bu konuda üniversite öğrencileri üzerinde yapılan araştırmalarda STYY'nin öğrencilerin yazma kaygılarını azalttı̆̆ı, yazma başarılarını artırdığı tespit edilmiştir (Bayat, 2014; Ho, 2006). Bu yaklaşımın öğrencilerin yazma isteklerini artırdığı belirtilmiştir (Duijnhouwer, Prins, \& Stokking, 2012; Mehr, 2017; Reimer, 2001; Zhou, 2015). STYY, öğrencilerin yazma öz yeterliliklerini, yazma karş1 ilgi ve isteklerini artırmakta ve yazmaya karşı olumlu tutum geliştirmelerini desteklemektedir (Hamid, 2017). Ayrıca STYY'nin yazamayan öğrencileri bile yazmaya güdülediği belirtilmişsir (Yılmaz, 2012). Deneysel yöntemle gerçekleştirilen bir araştırmada, süreç temelli yaratıcı yazma uygulamalarının öğrencilerin yazma tutumlarını ve becerilerini olumlu yönde etkilediği sonucuna ulaşıılmıştır (Erdoğan \& Yangın, 2014). STYY'nin yazmaya yönelik tutumu olumlu yönde etkilediği tespit edilmiştir (Balc1, 2017; Görgüç, 2016). Buna karşın bu yaklaşımın, öğrencilerin yazma tutumlarını etkilemediğine yönelik araştırmalar da bulunmaktadır (Selanikli, 2015; Aksu \& Karatay, 2017). Bu durum, araştırmada kullanılan örneklem grubundan kaynaklanıyor olabilir. Çünkü alandaki birçok çalışma, STYY'nin yazma tutumunu olumlu etkilediği sonucuna ulaşmıştır.

Süreç değerlendirme, öğrencilerin öğrenme süreci içerisinde gerçekleştirilen etkinliklerle hedeflenen kazanımlara sahip olabilme oranının belirlenmesinin ötesinde öğrenmenin daha iyi hale getirilmesini ve bilişsel, duyuşsal, psiko-motor becerilerinin bir bütünlük içerisinde gelişimini amaçlar (Göçer, 2014). Elde edilen görüşler kullanılan ölçme ve değerlendirmelerin bu amaca ulaştı̆ıını göstermektedir. Süreç temelli yazma uygulamalarında kullanılan ölçme ve değerlendirme araçlarının; yazma becerisini, bilişsel becerileri olumlu etkilediği; öğrenciyi aktif kıldığı söylenebilir. Fakat bu ölçme ve değerlendirme uygulamaları sırasında öğretmenlerin bütün öğrencilere 
dönüt vermesi, demokratik bir sınıf ortamı sağlaması noktasında güçlükler yaşandığına dair görüşler tespit edilmiştir. Bu konuda deneysel yöntemle gerçekleştirilmiş bir araştırmada öğretmenlerin geri dönüt vermesinin, öğrencilerin öz güvenlerini, yazma performans ve motivasyonlarını artırdığı sonucuna ulaşılmıştır (Duijnhouwer, Prins, \& Stokking, 2012). Yazma sürecinde öğretmen ve akranlardan alınan dönütler, yazma sürecini, motivasyon ve performansını olumlu etkilemektedir (Reimer, 2001; Zhou, 2015). Ayrıca akran geri bildiriminin, ögrencilerin üst bilişsel ve dil becerilerinin gelişimine katkı sağladığı bilinmektedir (Nguyen, 2016). Buna karşın akran değerlendirme sırasında öğrencilerin eleştirilmekten endişe duydukları, öz güven ve kaygı problemi yaşadıkları ortaya konulmuştur (Storch, 2005). Tüm bu araştırmalar olumlu ve olumsuz yönleriyle varılan sonucu güçlendirmektedir.

Öğrencilerin hazırbulunuşluk ve özgüven eksiklikleri; yaklaşımın içerdiği ölçme ve değerlendirme uygulamalarını, yazma becerisini ve süreç temelli yazma uygulamalarını olumsuz etkilediği belirtilmiştir. Ayrıca bu yaklaşımın; yazma işlemini sürece yayması, öğrenciyi aktif kılması, yazma gelişimi ve bütünsel gelişim açısılarından katkı sağladığı yönünde görüşler tespit edilmiştir. Bu konuda deneysel yöntemle gerçekleştirilen bir araştırmada STYY'nin yazma başarı ve alışkanlıklarına, özgüvenlerine, yazmaya yönelik olumlu tutum geliştirmelerine katkı sağladığı belirtilmiştir (Özenç, 2016). Yazma becerilerinin gelişimi ve yazma başarısı için STYY kullanılmalıdır (Jensen \& DiTiberio, 1984). STYY'nin öğrencilerin yazma motivasyonunu ve kaliteli metin yazabilmelerini desteklediği ortaya konulmuştur (Graham \& Sandmel, 2011). Alan yazındaki araştırmalar süreç temelli yazma uygulamalarının yazma becerisinin gelişimine katkı sağladığı konusunda birleşmekte ve araştırmanın bulgularını desteklemektedir.

\section{Teşekkür ve Bilgilendirme}

Bu çalışma “Süreç Temelli Yazma Yaklaşımının Uygulanabilirliğine İlişkin Öğretmen Görüşleri” adlı yüksek lisans seminerinden hareketle oluşturulmuştur. Araştırma sürecinin her aşamasında desteğini esirgemeyen, bilgi ve birikimleriyle bana yol gösteren değerli danışman hocam Dr. Öğr. Üyesi Sezgin DEMİR'e emeklerinden ötürü teşekkürü bir borç bilirim. Ayrıca bu araştırma, 2-5 Mayıs 2018 tarihinde Antalya'da gerçekleştirilen V. EJER Congress'de sözlü bildiri olarak sunulmuştur. 


\section{Referanslar}

Aksu, Ö. (2015). Planl yazma ve değerlendirme modelinin ortaokul sekizinci slnıf öğrencilerinin performans görevlerini hazırlamalarına etkisi. Yayımlanmamış yüksek lisans tezi. Abant İzzet Baysal Üniversitesi, Eğitim Bilimleri Enstitüsü, Bolu.

Badger, R., \& White, G. (2000). A process genre approach to teaching writing. ELT journal, 54(2), 153-160. DOI: https://doi.org/10.1093/elt/54.2.153

Balcı, O. (2017). 4+1 planl yazma ve değerlendirme modelinin 6. sinı öğrencilerinin yazma becerilerini ve yazılı anlatım tutumlarını gelişstirmeye etkisi. Yayımlanmamış yüksek lisans tezi. Abant İzzet Baysal Üniversitesi Eğitim Bilimleri Enstitüsü, Bolu.

Bayat, N. (2014). Sürece dayalı yazma yaklaşımının yazma başarısı ve kaygısı üstündeki etkisi. Kuram ve Uygulamada Eğitim Bilimleri, 14(3), 1123-1141. DOI: 10.12738/estp.2014.3.1720

Bilgin, N. (2014). Sosyal bilimlerde içerik analizi: teknikler ve örnek çalışmalar. Ankara: Siyasal Kitabevi.

Büyüköztürk, Ş., Çakmak, E. K., Akgün, Ö. E., Karadeniz, Ş. Demirel, F. (2014). Bilimsel araştırma yöntemleri. Pegem Akademi: Ankara.

Creswell, J. W., \& Plano Clark, V. L. (2015). Karma yöntem araştırmaları: tasarımı ve yürütülmesi. (Çev. Ed. Yüksel Dede ve Selçuk Beşir Demir). Ankara: Anı yayıncılık.

Creswell, J. W. (2016a). Araştırma deseni: nitel, nicel ve karma yöntem yaklaşımları. (Çev. Edt. Selçuk Beşir Demir). Ankara: Eğiten Kitap

Creswell, J. W. (2016b). Nitel araştırma yöntemleri: beş yaklaşıma göre nitel araştırma yöntemleri. (Çev. Ed. Mesut Bütün ve Selçuk Beşir Demir). Ankara: Siyasal Kitabevi.

Duijnhouwer, H., Prins, F. J. \& Stokking, K. M. (2012). Feedback providing improvement strategies and reflection on feedback use: Effects on students' writing motivation, process, and performance. Learning and Instruction, 22(3), 171-184. DOI: https://doi.org/10.1016/j.learninstruc.2011.10.003

Duman, B. (2011). Süreç temelli öğrenme-öğretim modeli. Sosyal ve Beşeri Bilimler Araştırmaları Dergisi, $1(19)$.

Erdoğan, Ö. (2014). Süreç temelli yaratıcı yazma uygulamalarının yazıll anlatıma ve yazmaya ilişsin tutuma etkisi. Yayımlanmamış doktora lisans tezi. Hacettepe Üniversitesi, Sosyal Bilimler Enstitüsü, Ankara.

Erdoğan, Ö., \& Yangın, B. (2014). Süreç temelli yaratıı yazma uygulamalarının yazılı anlatıma ve yazmaya ilişkin tutuma etkisi. Abant İzzet Baysal Üniversitesi Eğitim Fakültesi Dergisi, 14(1), 439-459. DOI: http://dx.doi.org/10.17240/aibuefd.2014.14.1-5000091521

Göçer, A. (2014). Türkçe eğitiminde ölçme ve değerlendirme. Ankara: Pegem Akademi Yayınları.

Gömleksiz, M. N., Sinan, A. T., \& Demir, S. (2010). İlköğretim Türkçe dersi öğretim programındaki yazma öğrenme alanının etkililiğinin değerlendirilmesi. Turkish Studies International Periodical For the Languages, Literature and History of Turkish or Turkic, 5(4), 1135-1173. DOI: 10.7827/TurkishStudies. 1835

Gömleksiz, M. N., Sinan, A. T., \& Demir, S. (2011). İlköğretim ikinci kademe Türkçe Dersi Öğretim Programi’ndaki "okuma” öğrenme alanina ilişkin kazanimlarin gerçekleşme düzeyine yönelik öğretmen görüşleri. Firat Üniversitesi Sosyal Bilimler Dergisi, 21(1), 169-196.

Görgüç, Ç., (2016). Analitik yazma ve değerlendirmenin 6. sinıf öğrencilerinin yazma tutumu ve yazma başarısına etkisi. Yayımlanmamış yüksek lisans tezi. Dokuz Eylül Üniversitesi Eğitim Bilimleri Enstitüsü, İzmir.

Graham, S., \& Sandmel, K. (2011). The process writing approach: A meta-analysis. The Journal of Educational Research, 104(6), 396-407. DOI: https://doi.org/10.1080/00220671.2010.488703

Güneş, F. (2007). Türkçe öğretimi ve zihinsel yapılandırma. Ankara: Nobel Yayın Dağıtım.

Hamid, S. (2017). The effect of reflection-supported process-based writing teaching on rraqi efl students' writing performance and attitude. Arab World English Journal (AWEJ), 7(4), 42-62. DOI: 10.17605/OSF.IO/8z9pf

Ho, B. (2006). Using the process approach to teach writing in 6 hong kong primary classrooms. New Horizons in Education, 53, 22-41.

Jensen, G. H., \& DiTiberio, J. K. (1984). Personality and individual writing processes. College Composition 
and Communication, 35(3), 285-300. DOI: 10.2307/357457

Johari, S. K. (2018). The Effects of Task-Based Process Writing Approach on the Academic Writing Skills among Second Language Tertiary Learners. Journal of ELT Research, 3(1), 1-20. DOI: https://doi.org/10.22236/JER_Vol3Issue1pp1-20

Kallestinova, E. (2017). Crafting an Argument in Steps: A Writing Process Model for Graduate and Professional Students with LD. Learning Disabilities: A Contemporary Journal, 15(1), 15-37.

Karasar, N. (2009). Bilimsel araştırma yöntemi. Ankara: Nobel Yayıncılık.

Karatay, H. (2011). 4+ 1 planlı yazma ve değerlendirme modelinin öğretmen adaylarının yazılı anlatım tutumlarını ve yazma becerilerini geliştirmeye etkisi. Turkish Studies, 6(3), 1029-1047. DOI: 10.7827/TurkishStudies. 2622

Karatay, H. (2014). Süreç temelli yazma modelleri: Planlı yazma ve değerlendirme. M. Özbay (Ed.), Yazma Ĕgitimi, 2, 21-43. Ankara: Pegem Akademi.

Karatay, H., \& Aksu Ö., (2017). 4+ 1 Planlı Yazma ve Değerlendirme Modeli’nin 8. sınıf öğrencilerinin ev ödevlerini hazırlamaya etkisi. Ana Dili Eğitimi Dergisi, 5(2), 313-335. DOI: 10.16916/aded.302765

Karatosun. S. (2014). Planli yazma ve değerlendirme modelinin ilköğretim 5. sinif öğrencilerinin kompozisyon yazma becerilerini geliştirmeye etkisi. Yayımlanmamış yüksek lisans tezi. Mustafa Kemal Üniversitesi, Sosyal Bilimler Enstitüsü, Hatay.

Krendl, K. A., \& Dodd, J. (1987). Assessing the National Writing Project: A Longitudinal Study of ProcessBased Writing. https://files.eric.ed.gov/fulltext/ED289167.pdf

Maden, S., Dincel, Ö., \& Maden, A. (2015). Türkçeyi yabancı dil olarak öğrenenlerin yazma kaygıları. Uluslararası Türkçe Edebiyat Kültür Eğitim (TEKE) Dergisi, 4(2), 748-769. DOI: http://dx.doi.org/10.7884/teke.488

Mehr, H. S. (2017). The Impact of Product and Process Approach on Iranian EFL Learners' Writing Ability and Their Attitudes toward Writing Skill. International Journal of English Linguistics, 7(2), 158-166. DOI: https://doi.org/10.5539/ijel.v7n2p158

Miles, M. B., \& Huberman, A. M. (2016). Genişletilmiş bir kaynak kitap: nitel veri analizi. (S. A. Altun, A. Ersoy Çev.). Ankara: Pegem Akademi.

Nguyen, H. T. (2016). Peer feedback practice in efl tertiary writing classes. English Language Teaching, 9(6), 76-91. DOI: http://dx.doi.org/10.5539/elt.v9n6p76

Nordin, S. M. (2017). The best of two approaches: Process/genre-based approach to teaching writing. The English Teacher, 11, 75-85.

Okari, F. M. (2016). The writing skill in the contemporary society: the kenyan perspective. Journal of Education and Practice, 7(35), 65-69.

Özenç, E. G. (2016). The effect of process oriented writing activities on the achievement and attitude of the preservice primary school teachers: An example of mixed method study. Journal of Education and Training Studies, 4(11), 227-237.

Patton, M.Q. (2014). Nitel araştırma ve değerlendirme yöntemleri. (Çev. Ed. Mesut Bütün ve Selçuk Beşir Demir Ankara: Pegem Akademi.

Reimer, C. N. (2001). Strategies for teaching writing to primary students using the writing process. Master's Thesis, Biola University.

Selanikli, E. (2015). 4+1 planlı yazma ve değerlendirme modelinin 7. sınıföğrencilerinin performans görevlerini ve proje ödevlerini hazırlamalarına etkisi. Yayımlanmamış yüksek lisans tezi. Abant İzzet Baysal Üniversitesi, Eğitim Bilimleri Enstitüsü, Bolu.

Seow, A. (2002). The writing process and process writing.

(J. C. Richards, \& W. A. Renandya Ed.).Methodology in language teaching: An anthology of current practice, 315-320.

Sever, E. (2013). Süreç temelli yazma modellerinin ilkokul dördüncü sınıf ögrencilerin yazılı anlatım ve yaratıcı yazma becerilerine etkisi. Yayımlanmamış yüksek lisans tezi. Abant İzzet Baysal Üniversitesi, Eğitim Bilimleri Enstitüsü, Bolu. 
Sezgin, N. (2016). Süreç temelli yazma öğretiminin hafif düzeyde zihinsel yetersizliği olan öğrencinin yazma becerisine etkisinin incelenmesi. Yayımlanmamış yüksek lisans tezi. Karadeniz Teknik Üniversitesi, Eğitim Bilimleri Enstitüsü, Trabzon.

Silva, T. (1990). Second language composition instruction: Developments, issues, and directions. in ESL. Barbara Kroll (Ed.). Second language writing: Research insights for the classroom, 11-23.

Sönmez, V., \& Alacapınar, F. G. (2016). Sosyal bilimlerde ölçme aracı hazırlama. Ankara: Anı Yayıncılık.

Storch, N. (2005). Collaborative writing: Product, process, and students' reflections. Journal of second language writing, 14(3), 153-173. DOI: https://doi.org/10.1016/j.jslw.2005.05.002

Şahin, S. (2007). Güzel, etkili konuşma ve yazma sanatı. İstanbul: İnkılap Kitapevi.

Şentürk, N. (2009). Planlı yazma ve değerlendirme modelinin 8. sinıf ögrencilerinin bilgilendirici metin yazma becerilerini geliştirmeye etkisi. Yayımlanmamış yüksek lisans tezi. Abant İzzet Baysal Üniversitesi, Sosyal Bilimler Enstitüsü, Bolu.

Tuan, L. T. (2011). Teaching Writing through Genre-based Approach. Theory \& Practice in Language Studies, l(11), 1471-1478. DOİ:10.4304/tpls.1.11.1471-1478

Türnüklü, A. (2000). Eğitimbilim araştırmalarında etkin olarak kullanılabilecek nitel bir araştırma tekniği: görüşme. Kuram ve Uygulamada Ĕ̆itim Yönetimi, 24, 543-559.

Ülper, H. (2009). Bilişsel süreç modeline göre hazırlanan yazma öğretimi izlencesinin ögrenci başarısına etkisi. Yayımlanmamış doktora lisans tezi. Ankara Üniversitesi, Sosyal Bilimler Enstitüsü, Ankara.

Yılmaz, M. (2012). İlköğretim 1. kademe öğrencilerinin kompozisyon yazma becerilerini geliştirmede planlı yazma modelinin önemi. Mustafa Kemal Üniversitesi Sosyal Bilimler Enstitüsü Dergisi, 9(19), 321-330.

Yılmaz, M., \& Aklar, S. (2015). Planlı yazma ve değerlendirme modelinin ilköğretim 5. sınıf öğrencilerinin kompozisyon yazma becerilerine etkisi. Bartın Üniversitesi Eğitim Fakültesi Dergisi, 223-234. DOI: 10.14686/BUEFAD.2015USOSOzelsayi13212

Zare-ee, A., \& Mahdavi, F. (2014). Researching aptitude in a process-based approach to foreign language writing instruction. Advances in Language and Literary Studies, 5(5), 22-27. Doi:10.7575/aiac.alls.v.5n.5p.22

Zhou, D. (2015). An empirical study on the application of process approach in non-english majors' writing. English Language Teaching, 8(3), 89-96. DOI: http://dx.doi.org/10.5539/elt.v8n3p89 